\title{
Regulable aggregation-induced emission supramolecular polymer and gel based on self- sorting assembly
}

Hui Li, ${ }^{*}{ }^{\dagger}$ Zhaozhao Duan, ${ }^{\dagger}$ Ying Yang, ${ }^{\dagger}$ Fenfen $\mathrm{Xu},{ }^{\dagger}$ Mingfei Chen, ${ }^{\dagger}$ Tongxiang Liang, ${ }^{\dagger}$ Yang Bai, ${ }^{*}+$ and Riqiang $\mathrm{Li}^{\dagger}$

$\dagger$ School of Materials Science and Engineering, Jiangxi University of Science and Technology, Ganzhou 341000, P. R. China.

$\$$ Shaanxi Key Laboratory of Chemical Additives for Industry, College of Chemistry and Chemical Engineering, Shaanxi University of Science and Technology, Xi'an 710021, China.

* E-mail: 1h@jxust.edu.cn (H. L.)

*E-mail: baiyang@sust.edu.cn (Y. B.)

\section{Supporting information}

1. Self-sorting binding studies based on model compounds......................2

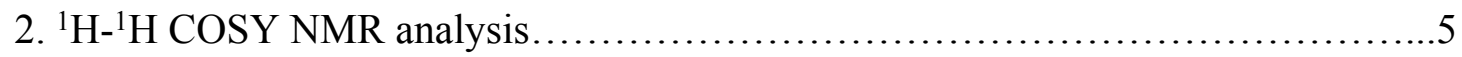

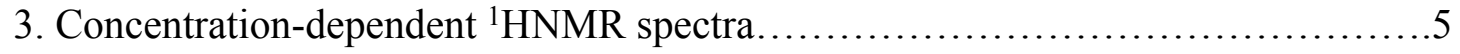

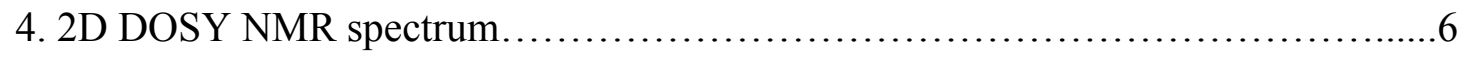

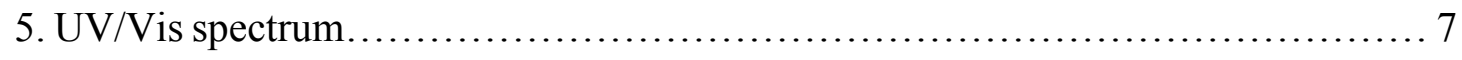

6. Disassembly and reassembly of supramolecular cross-linked alternating polymer...7

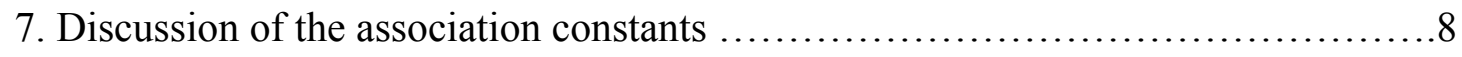

8. Synthesis of the intermediates and monomers............................ 9 
1. Self-sorting binding studies based on model compounds

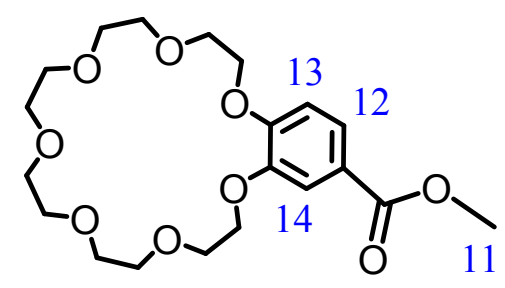

H1

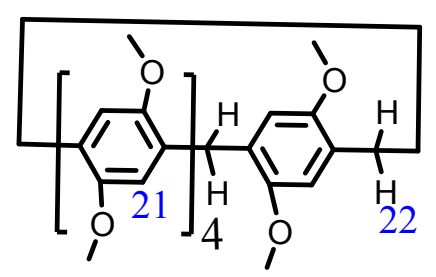

H2

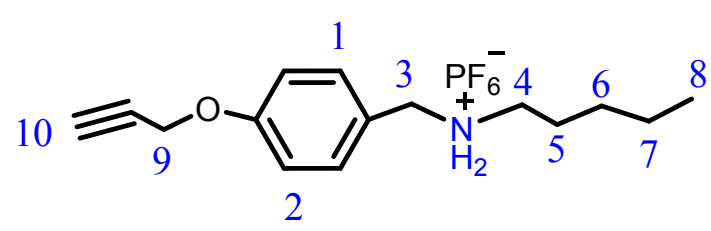

G1

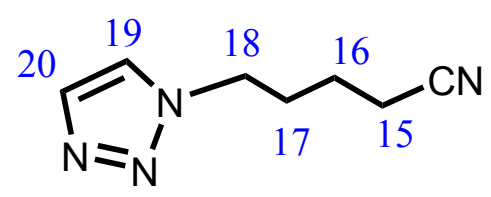

G2

Scheme S1 Structures of model compounds

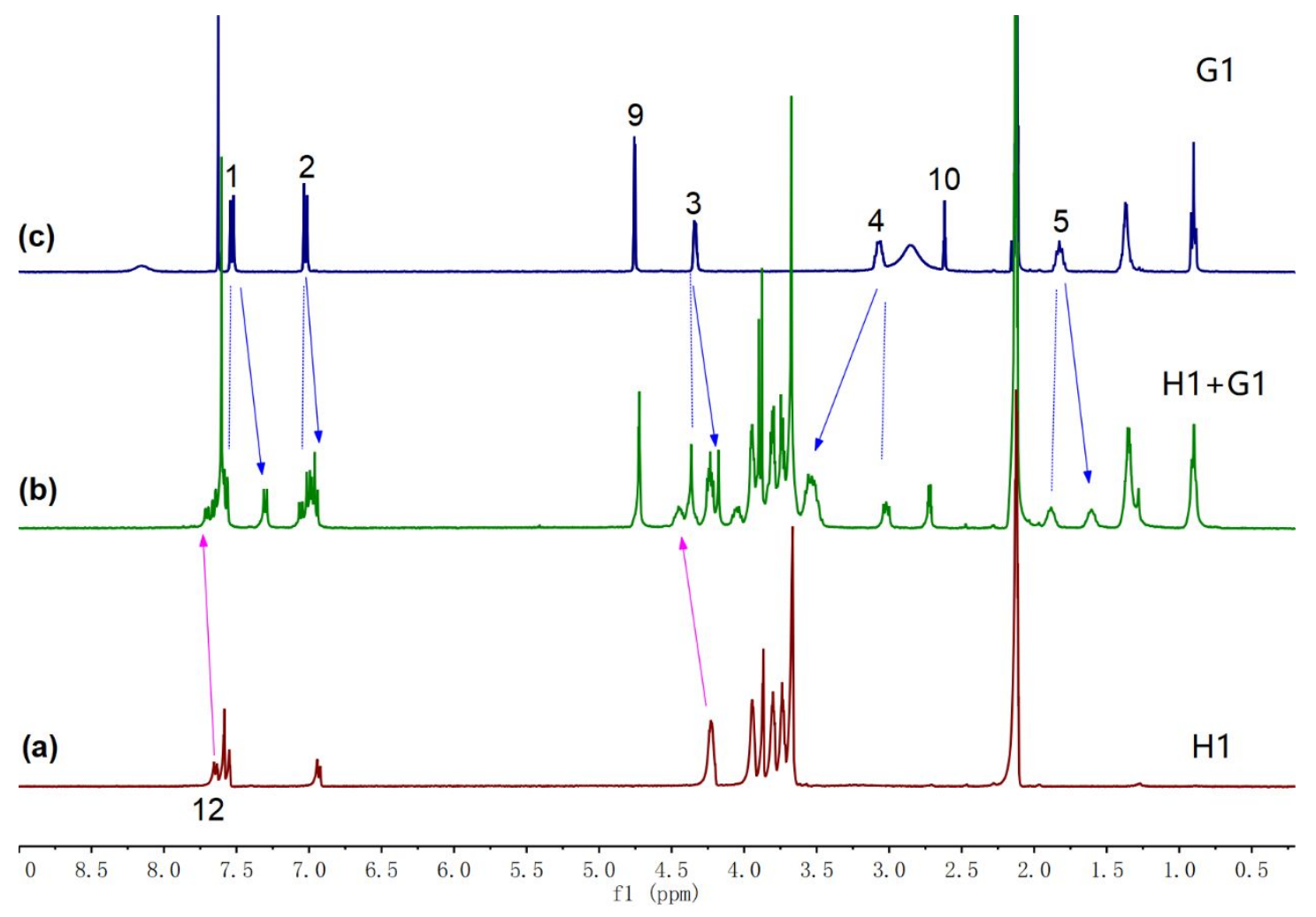


Fig. S1. ${ }^{1} \mathrm{H}$ NMR spectrum (400 MHz, chloroform- $d_{3} /$ acetone- $d_{6}(2 / 1, v / v), 298 \mathrm{~K}$ ) of (a) H1, (b) an equimolar solution of H1 and G1, (c) G1. Signals affiliated with solvents are denoted by star symbols.

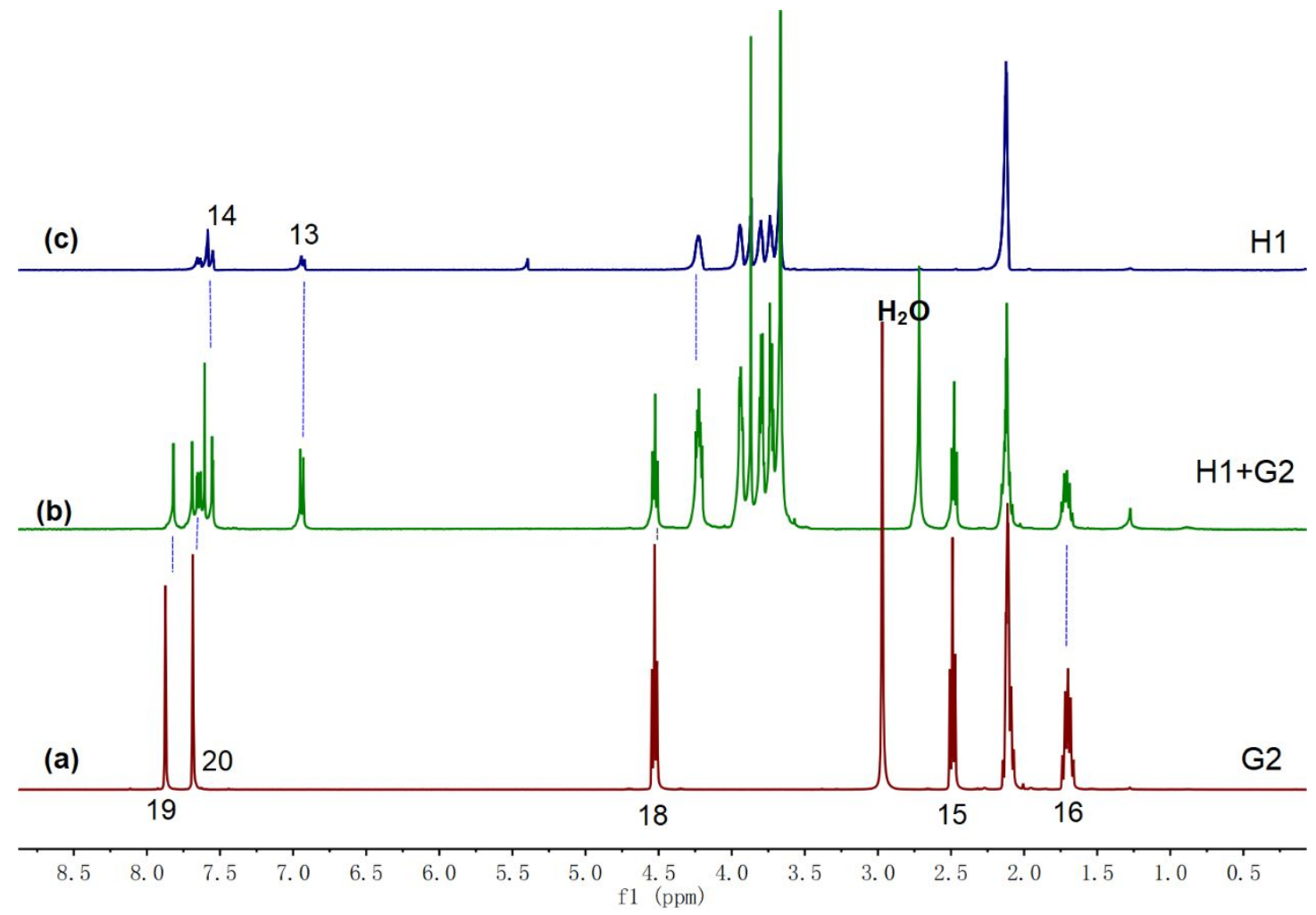

Fig. S2. ${ }^{1} \mathrm{H}$ NMR spectrum (400 MHz, chloroform- $d_{3} /$ acetone- $d_{6}(2 / 1, v / v), 298 \mathrm{~K}$ ) of (a) $\mathrm{G} 2$, (b) an equimolar solution of H1 and G2, (c) H1. Signals affiliated with solvents are denoted by star symbols.

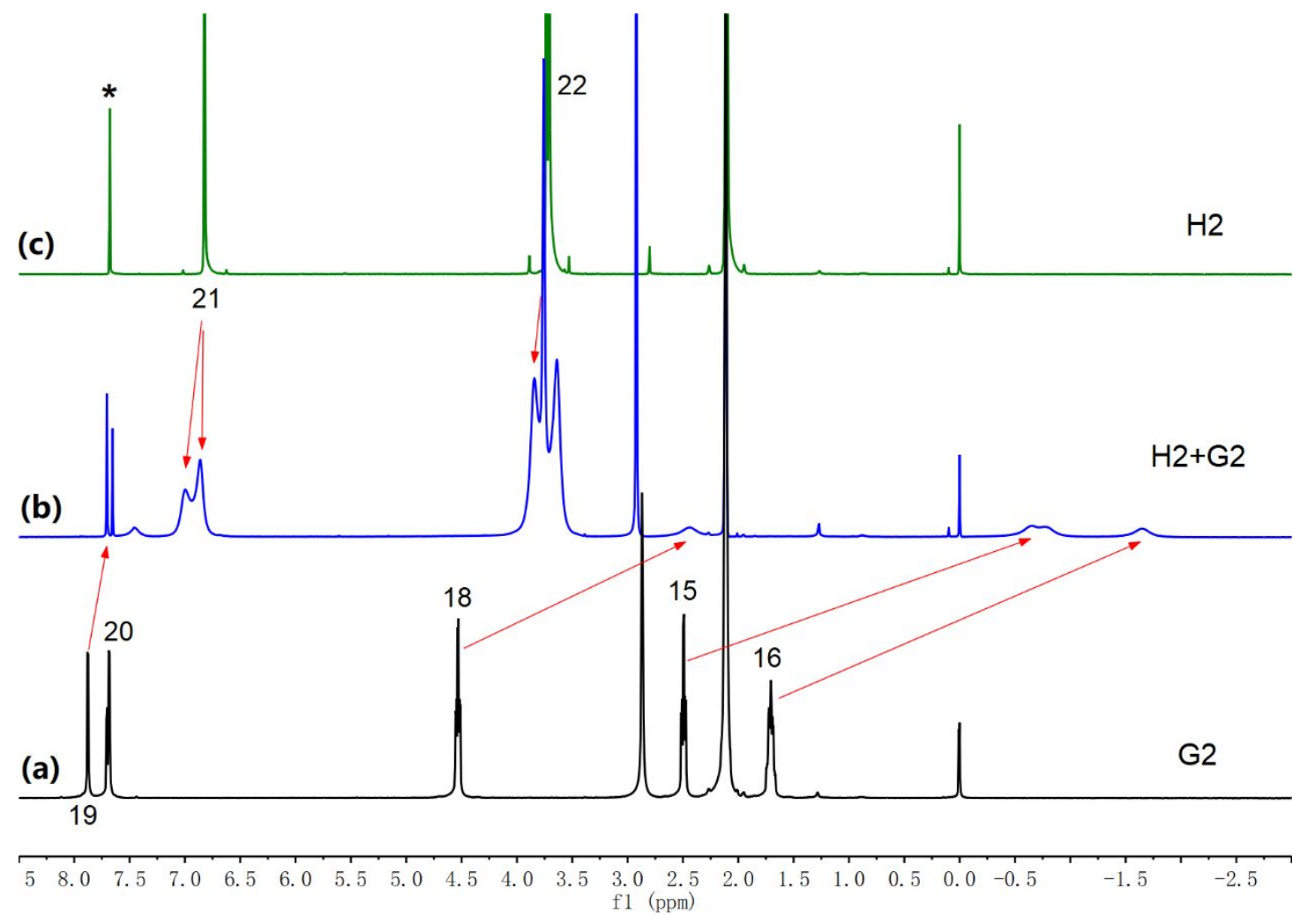

Fig. S3. ${ }^{1} \mathrm{H}$ NMR spectrum (400 MHz, chloroform- $d_{3} /$ acetone- $\left.d_{6}(2 / 1, v / v), 298 \mathrm{~K}\right)$ of (a) $\mathrm{G} 2$, (b) an equimolar 
solution of $\mathrm{H} 2$ and G2, (c) H2. Signals affiliated with solvents are denoted by star symbols.

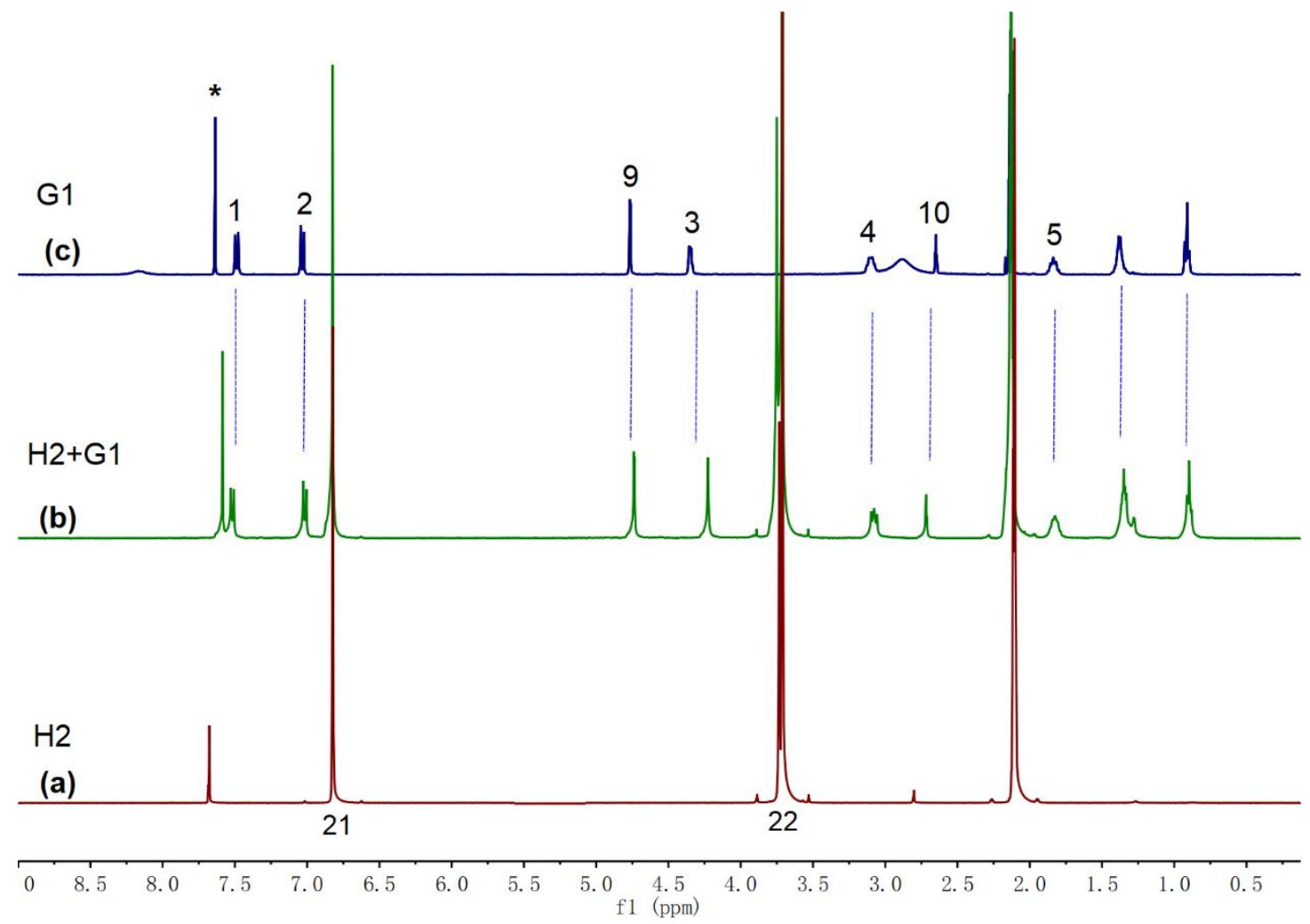

Fig. S4. ${ }^{1} \mathrm{H}$ NMR spectrum (400 MHz, chloroform- $d_{3} /$ acetone- $d_{6}(2 / 1, v / v), 298 \mathrm{~K}$ ) of (a) H2, (b) an equimolar solution of H2 and G1, (c) G1. Signals affiliated with solvents are denoted by star symbols.

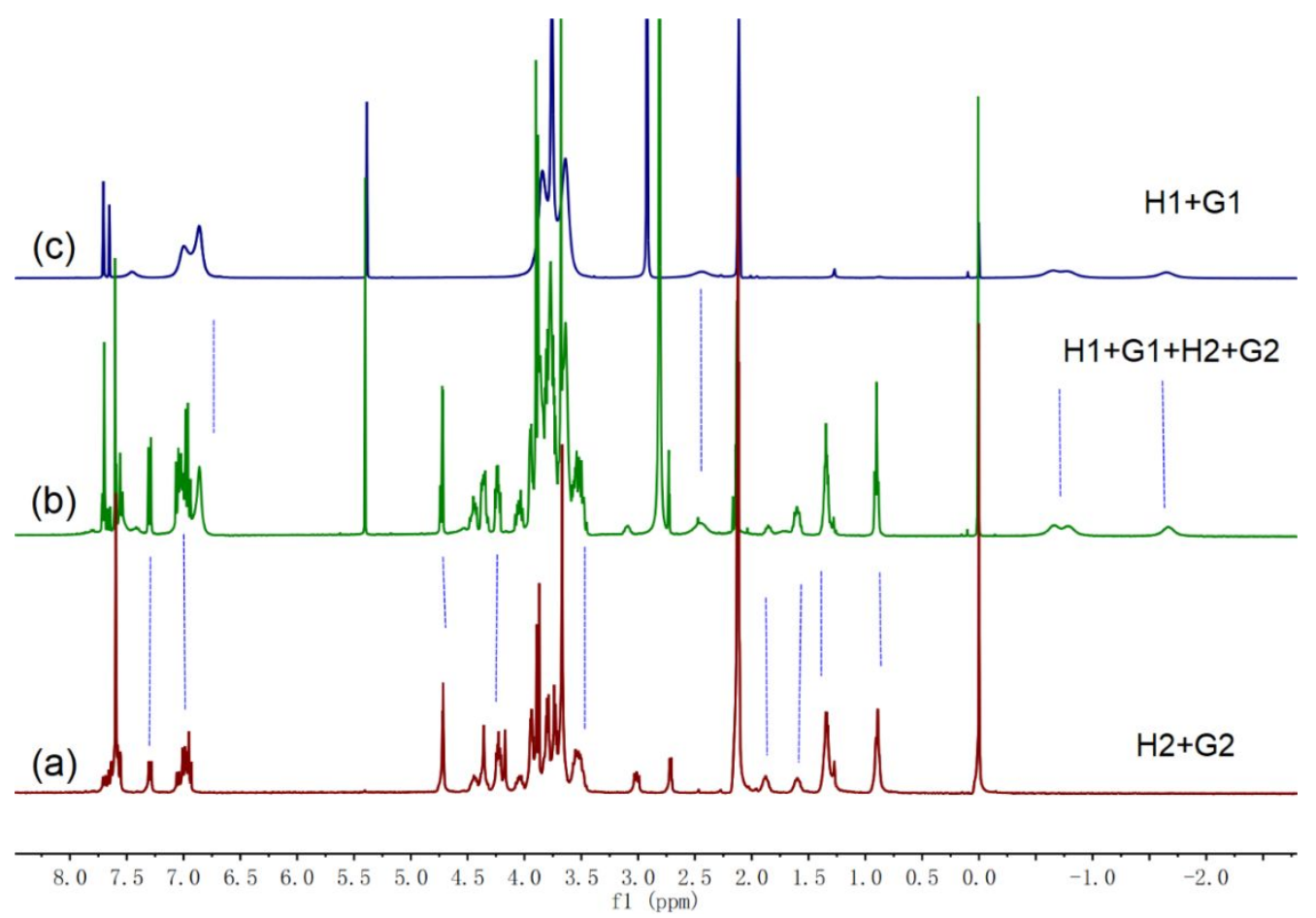

Fig. S5. ${ }^{1} \mathrm{H}$ NMR spectrum (400 MHz, chloroform- $d_{3} /$ acetone- $\left.d_{6}(2 / 1, v / v), 298 \mathrm{~K}\right)$ of (a) an equimolar solution of $\mathrm{H} 2$ and G2, (b) an equimolar solution of H1, G1, H2, and G2, (c) H1+G1. Signals affiliated with solvents are denoted by star symbols. 


\section{2. ${ }^{1} \mathrm{H}-{ }^{1} \mathrm{H}$ COSY NMR analysis}

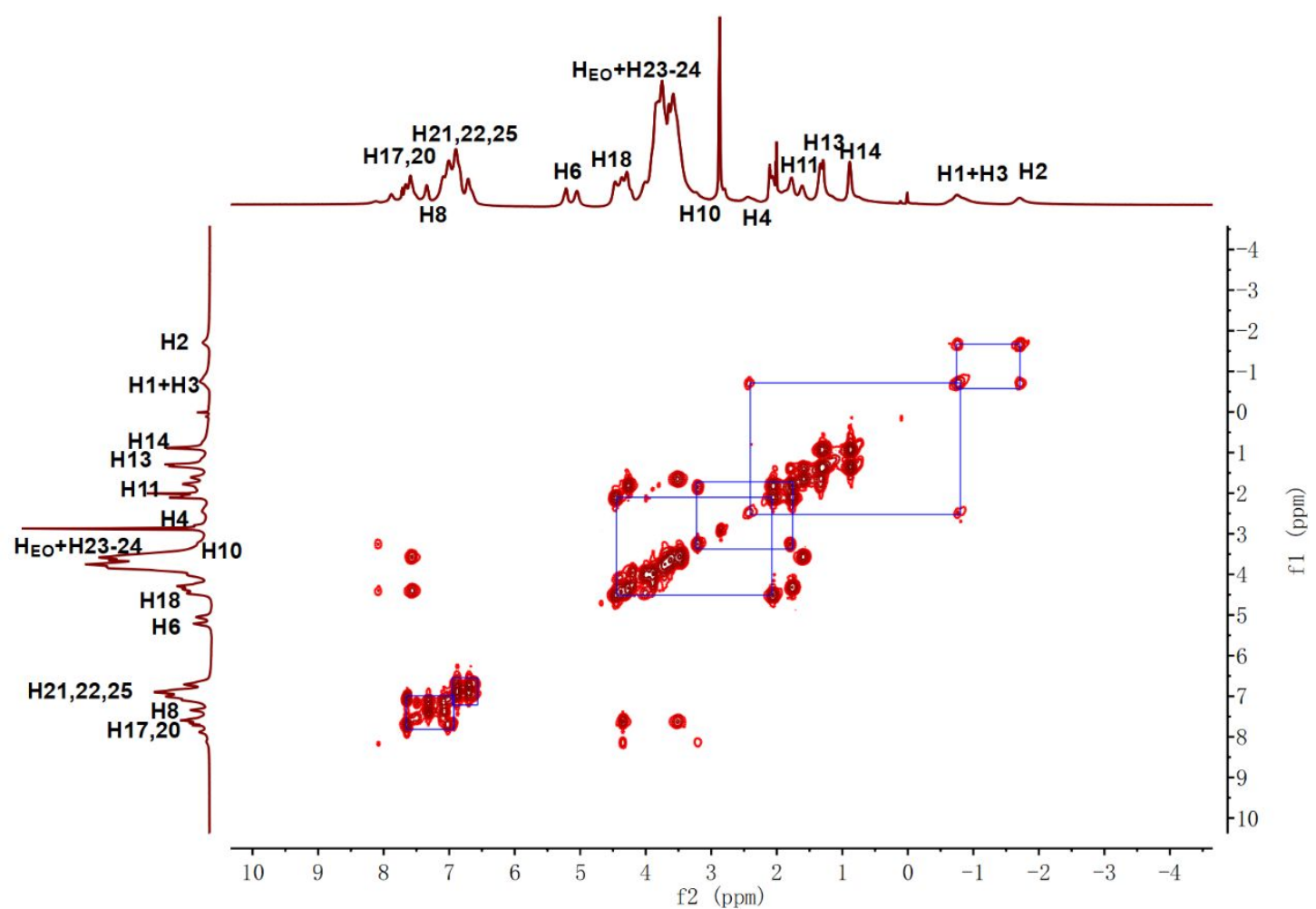

Fig. S6 ${ }^{1} \mathrm{H}-{ }^{1} \mathrm{H}$ COSY NMR (400 MHz, $\mathrm{CDCl}_{3}-\mathrm{CD}_{3} \mathrm{COCD}_{3}=2 / 1$, v/v, $\left.298 \mathrm{~K}, 30 \mathrm{mM}\right)$ spectrum of a solution of $\mathrm{M}_{4}$, $\mathrm{N}_{4}$, and AE. The strong correlations between the protons $\mathrm{H}_{1}$ and $\mathrm{H}_{2}, \mathrm{H}_{3}$ and $\mathrm{H}_{4}, \mathrm{H}_{10}$ and $\mathrm{H}_{11}$ on AE were observed, the correlation between $\mathrm{H}_{20}$ and $\mathrm{H}_{21}$ on M4 was also observed at the same time. By means of the ${ }^{1} \mathrm{H}-{ }^{1} \mathrm{H}$ COSY experiment and the ${ }^{1} \mathrm{HNMR}$ spectra comparison of four model compounds, the complicated ${ }^{1} \mathrm{H}$ NMR spectra of M4+N4+AE can be accurately identified.

\section{Concentration-dependent ${ }^{1}$ HNMR spectra}




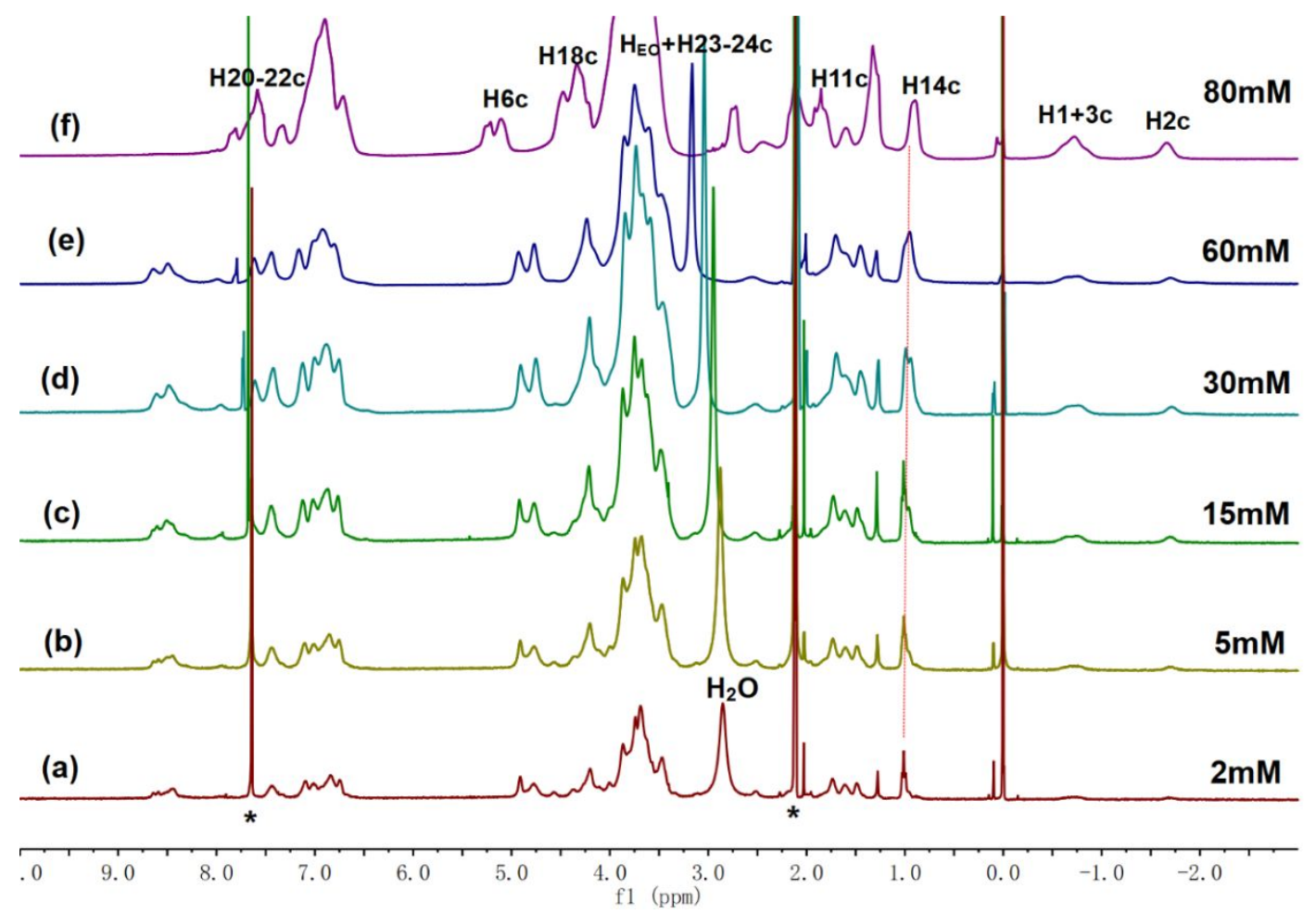

Fig. S7 ${ }^{1} \mathrm{H}$ NMR spectra $\left(400 \mathrm{MHz}, \mathrm{CDCl}_{3}-\mathrm{CD}_{3} \mathrm{COCD}_{3}=2 / 1, \mathrm{v} / \mathrm{v}, 298 \mathrm{~K}\right)$ of mixtures of 1:1:4 molar ratio of M4, N4, AE at different AE concentrations: (a) $2 \mathrm{mM}$, (b) $5 \mathrm{mM}$, (c ) $15 \mathrm{mM}$, (d) $30 \mathrm{mM}$, (e) $60 \mathrm{mM}$, (f) $80 \mathrm{mM}$. Peaks of complexed monomers are designated as c, signals affiliated with solvents are denoted by star symbols.

\section{2D DOSY NMR spectrum}

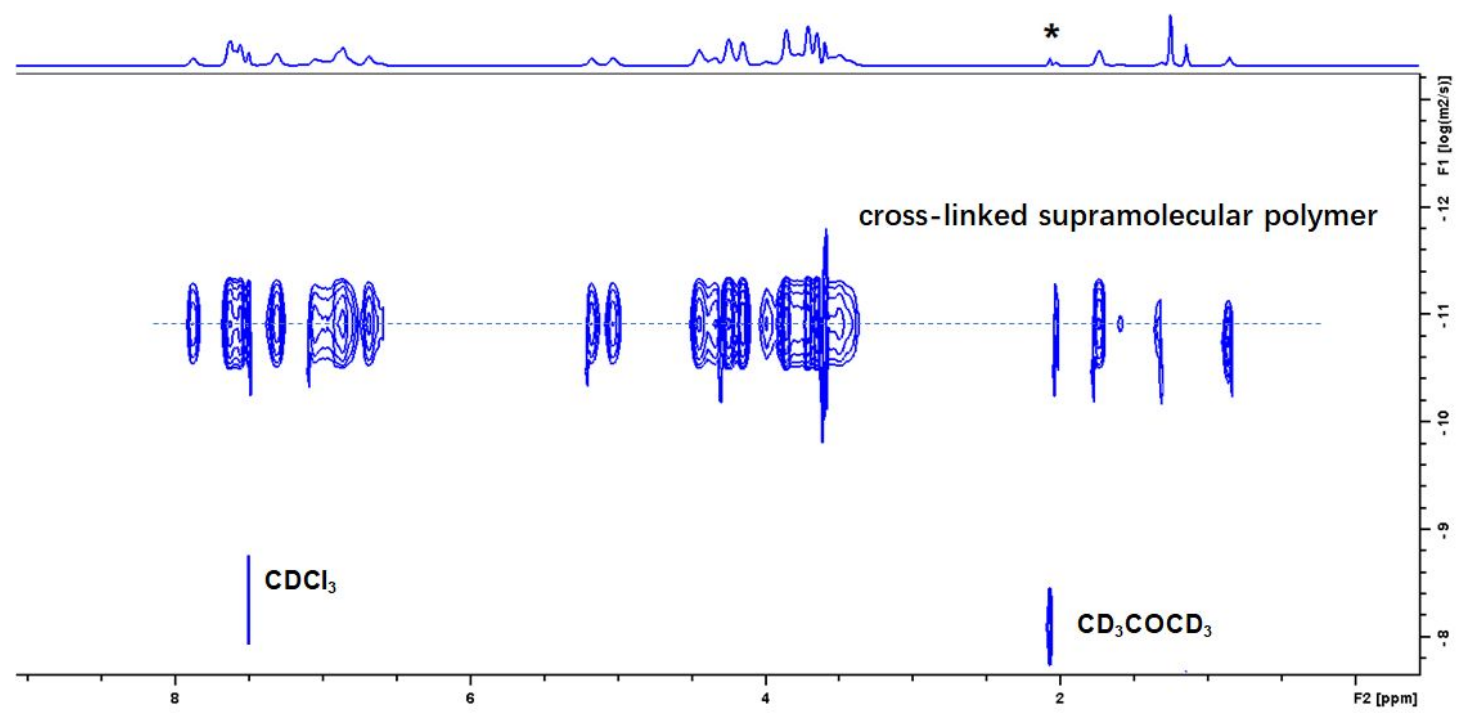

Fig. S8 Representative DOSY spectrum $\left(500 \mathrm{MHz}, \mathrm{CDCl}_{3}-\mathrm{CD}_{3} \mathrm{COCD}_{3}=2 / 1\right.$, v/v, $\left.298 \mathrm{~K}\right)$ of 1:1:4 molar ratio of $\mathrm{M} 4, \mathrm{~N} 4$, and $\mathrm{AE}$, the $\mathrm{AE}$ concentration is $75 \mathrm{mM}$. 
5. UV/Vis spectrum

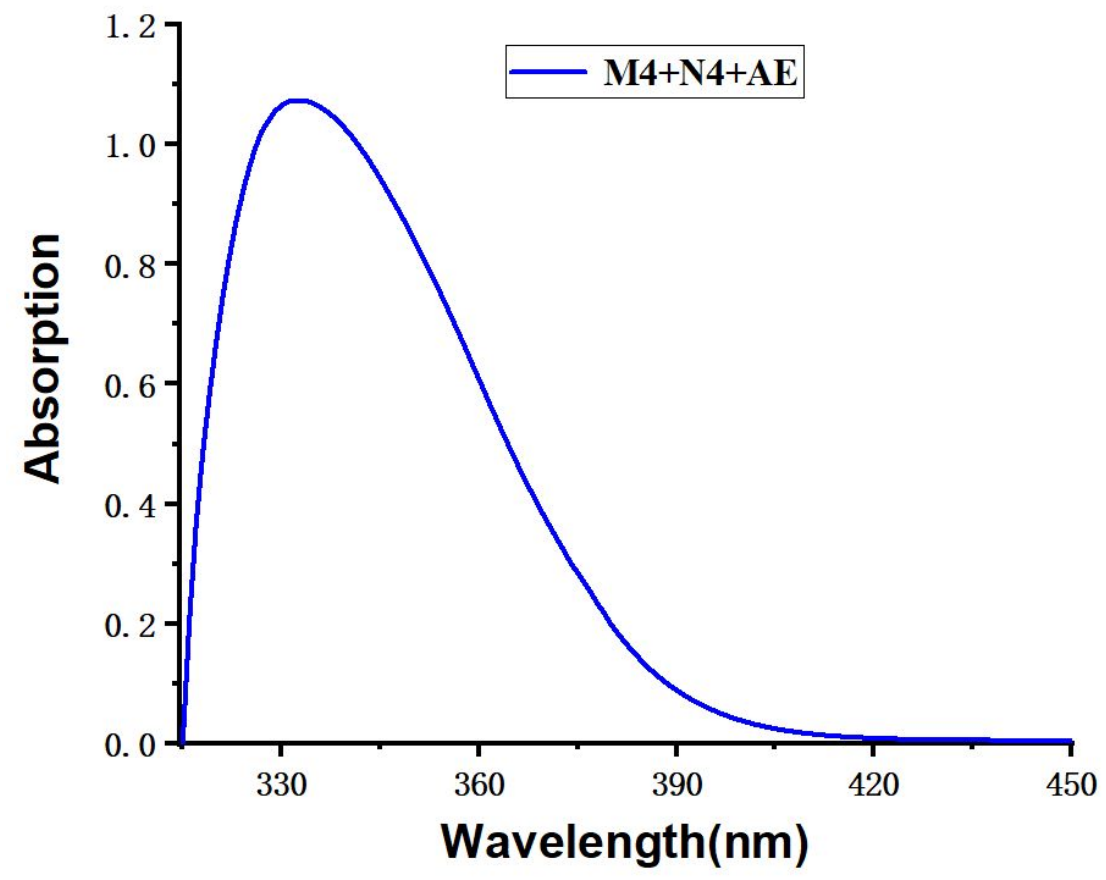

Fig. S9 The UV/Vis absorption spectrum of $0.05 \mathrm{mM}$ solution of $\mathrm{M} 4+\mathrm{N} 4+\mathrm{AE}$ in $\mathrm{CHCl}_{3}-\mathrm{CH}_{3} \mathrm{COCH}_{3}(2 / 1, \mathrm{v} / \mathrm{v})$.

6. Disassembly and reassembly of supramolecular cross-linked alternating polymer 


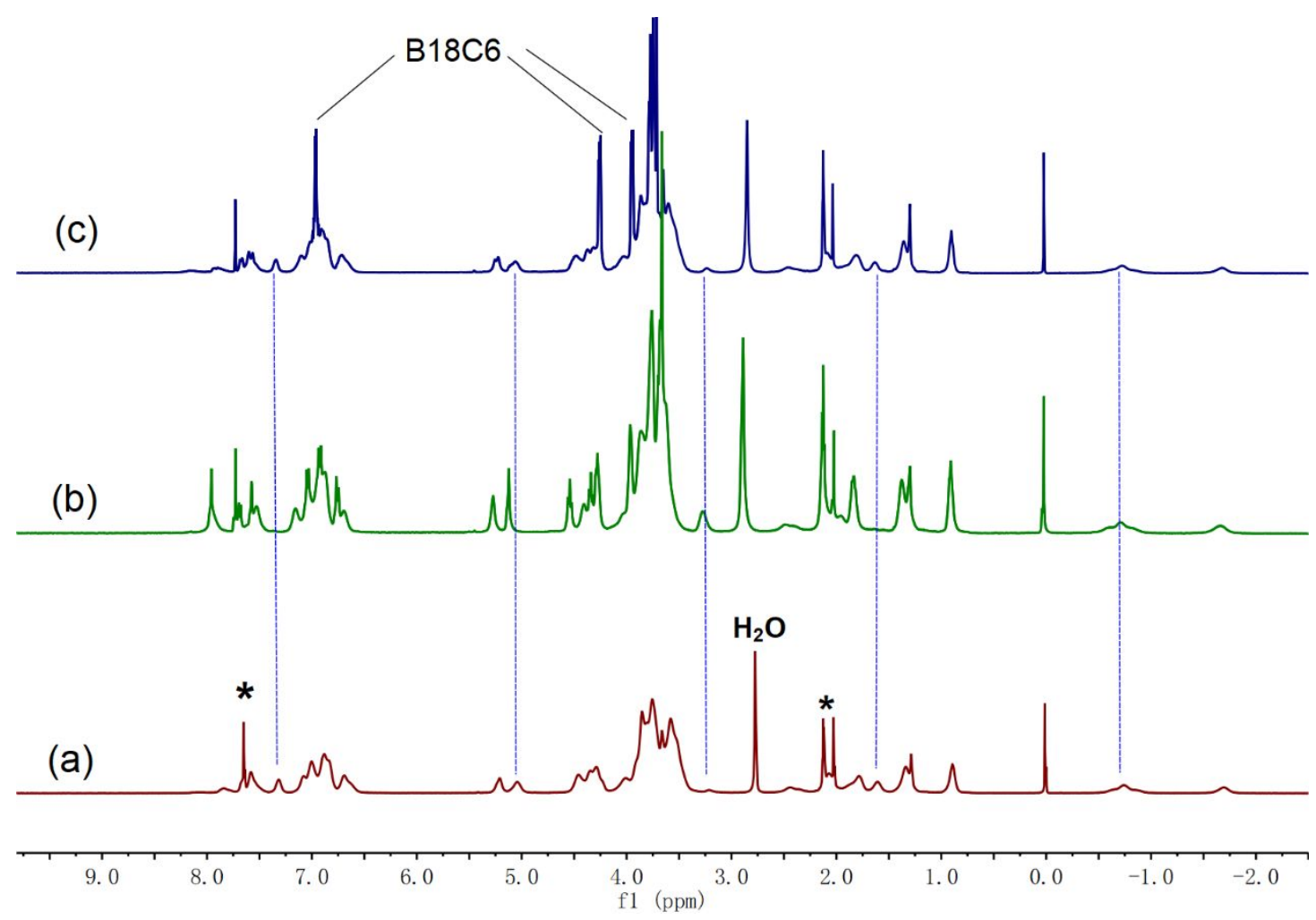

Fig. S10 ${ }^{1} \mathrm{H}$ NMR spectra (400 MHz, $\mathrm{CDCl}_{3}-\mathrm{CD}_{3} \mathrm{COCD}_{3}=2 / 1$, v/v, $\left.298 \mathrm{~K}, 20 \mathrm{mM}\right)$ of a solution of 1:1:4 molar ratio of M4, N4, and $\mathrm{AE}(\mathrm{a})$, after the addition of 4 equiv. $\mathrm{KPF}_{6}(\mathrm{~b})$, and after the addition of 4.8 equiv. B18C6 (c).

\section{Discussion of the association constants}

\section{(1) B21C-TAS binding interaction:}

Model compound B21C and DAS was used to determine the association constant $K_{a}$ of the Benzo-21-Crown-7/Dialkylammonium Salt system according to the reported literature method. ${ }^{\mathrm{S} 1}$ The $K_{\mathrm{a}}$ value of B21C-DAS complexes, slow-exchanging interaction, could be calculated from integrations of complexed and uncomplexed peaks in ${ }^{1} \mathrm{H}$ NMR spectra. The $K_{\mathrm{a}}$ value was determined at $5.00 \mathrm{mM} \mathrm{B} 21 \mathrm{C}$ and DAS in $\mathrm{CDCl}_{3} / \mathrm{CD}_{3} \mathrm{COCD}_{3}(2 / 1, \mathrm{v} / \mathrm{v})$ solution. Using the literature method, Ka value was calculated as below: $\left[(1.39 / 2.39) \times 5 \times 10^{-3}\right] /[(1-1.39 / 2.39) \times 5 \times$ $\left.10^{-3}\right]^{2}=665 \mathrm{M}^{-1}$ in $\mathrm{CDCl}_{3} / \mathrm{CD}_{3} \mathrm{COCD}_{3}$ solution $(2 / 1, \mathrm{v} / \mathrm{v})$, the experiment was repeated for three times and the average $K_{\mathrm{a}}$ was determined to be $675 \pm 55 \mathrm{M}^{-1}$, which is close to the literature value. ${ }^{\mathrm{S} 1}$ 


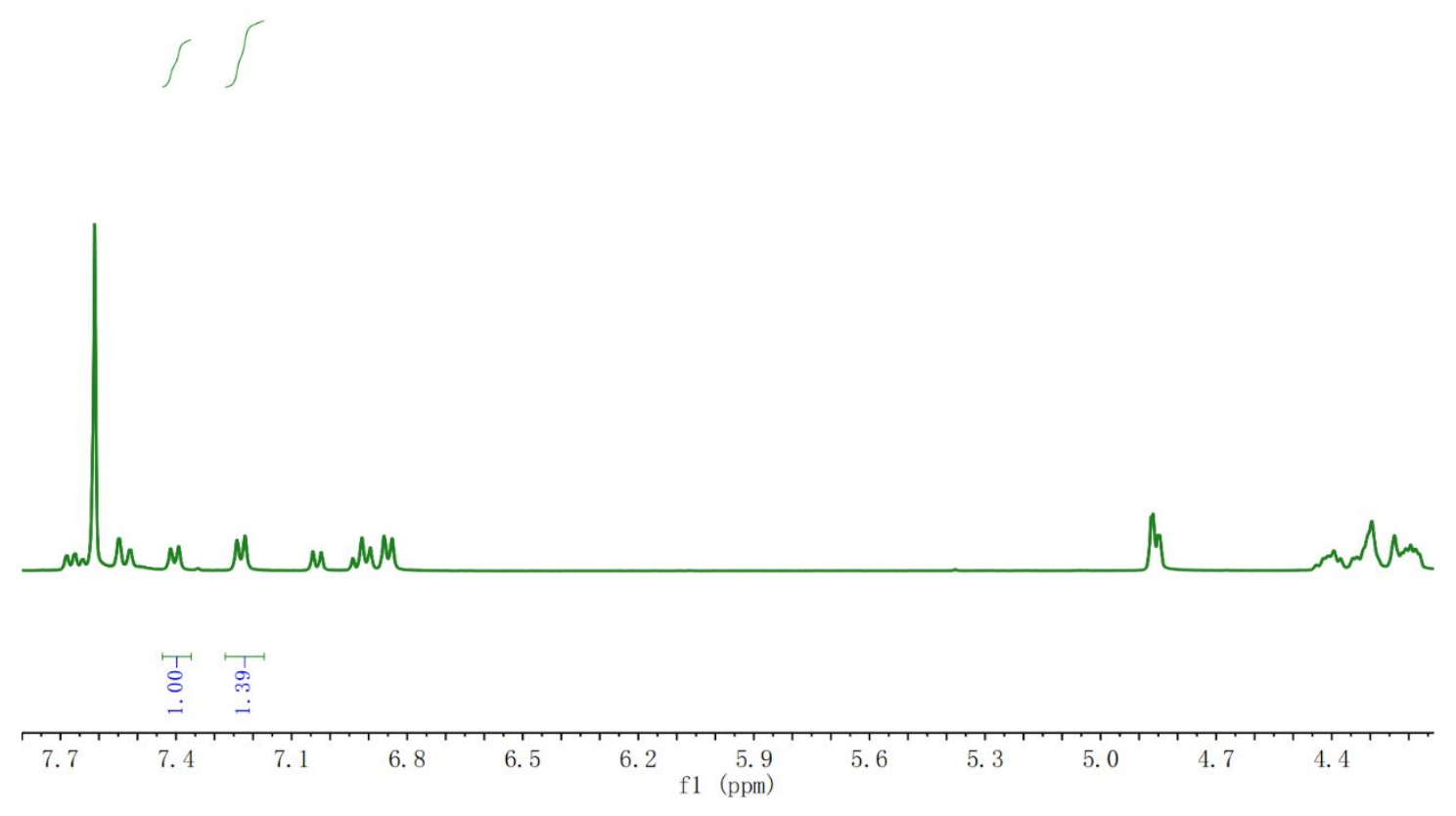

Fig. S11 ${ }^{1} \mathrm{HNMR}$ spectra (400 MHz, $\mathrm{CDCl}_{3} / \mathrm{CD}_{3} \mathrm{COCD}_{3}=1 / 1$, v/v, $\left.298 \mathrm{~K}\right)$ of $5.00 \mathrm{mM} \mathrm{B21C}$ and DAS.

\section{(2) P5-TAP binding interaction:}

The binding constant was referred by our previous work ${ }^{\mathrm{S} 2}: \mathrm{Ka}\{[\mathrm{P} 5 . \mathrm{TAP}] /[\mathrm{P} 5][\mathrm{TAP}]\}$ is equal to $(9.10 \pm 0.2) \times 10^{3} \mathrm{M}^{-1}$ in $\mathrm{CDCl}_{3} / \mathrm{CD}_{3} \mathrm{COCD}_{3}(2 / 1, \mathrm{v} / \mathrm{v})$.

\section{Synthesis of the intermediates and monomers}
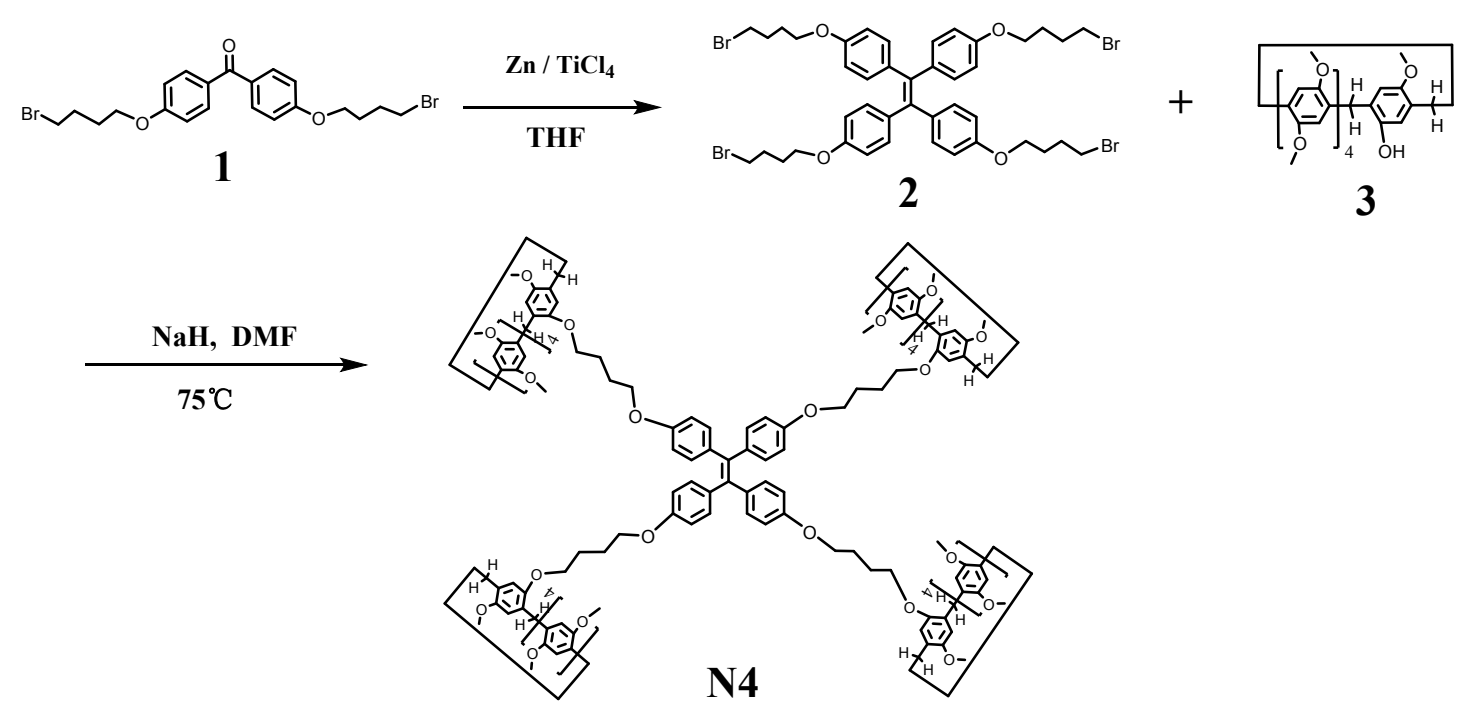


\section{Scheme S2. Synthetic route of monomer N4.}

\section{Synthesis of Compound 2}

To a solution of 4,4'-dibromobutoxybenzophenone $(2.0 \mathrm{~g}, 4.1 \mathrm{mmol})$ and zinc powder $(1.37 \mathrm{~g}, 20$ mmol) in THF $(100 \mathrm{~mL})$ was added dropwise $\mathrm{TiCl}_{4}(2.3 \mathrm{~g}, 12.1 \mathrm{mmol})$. After refluxing for $16 \mathrm{~h}$, the reaction mixture was cooled to room temperature and filtered. The solvent was evaporated under vacuum and the crude product was purified by column chromatography on silica gel using dichloromethane/petroleum ether $(v / v=1: 2)$ as the eluent. Finally, compound 2 was obtained as a white solid (1.99g, 52\%). ${ }^{1} \mathrm{HNMR}\left(400 \mathrm{MHz}, \mathrm{CDCl}_{3}, 298 \mathrm{~K}\right) \delta(\mathrm{ppm}): 6.92(\mathrm{~d}, J=8.8 \mathrm{~Hz}, 8 \mathrm{H})$, $6.61(\mathrm{~d}, J=8.8 \mathrm{~Hz}, 8 \mathrm{H}), 3.94(\mathrm{t}, J=6.4 \mathrm{~Hz}, 8 \mathrm{H}), 3.48(\mathrm{t}, J=6.6 \mathrm{~Hz}, 8 \mathrm{H}), 2.08-2.02(\mathrm{~m}, 8 \mathrm{H}), 1.94-$ $1.88(\mathrm{~m}, 8 \mathrm{H}) .{ }^{13} \mathrm{C} \mathrm{NMR}\left(100 \mathrm{MHz}, \mathrm{CDCl}_{3}, 298 \mathrm{~K}\right) \delta(\mathrm{ppm}): 157.0,136.9,132.5,113.5,66.6,33.5$, 29.7, 29.5, 27.9. HR-MALDI-TOF-MS $\left(\mathrm{C}_{218} \mathrm{H}_{236} \mathrm{O}_{44}\right): \mathrm{m} / \mathrm{z}$ calcd for $[\mathrm{M}]^{+}=936.0245$, found $=936.0281$, error $=3.8 \mathrm{ppm}$.

\section{중용요 \\ फं फं}
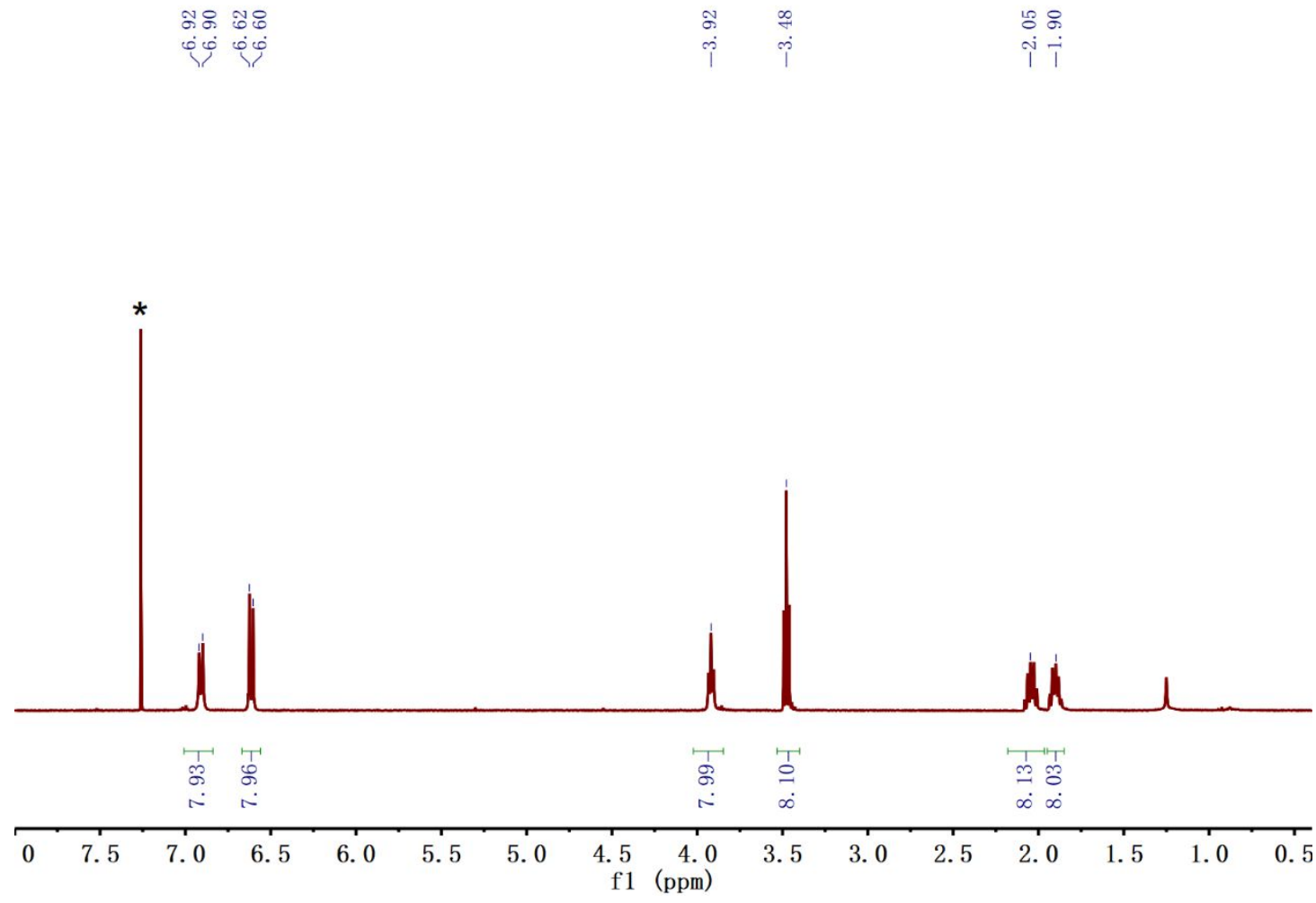

Fig. $\mathbf{S 1 2}{ }^{1} \mathrm{H}$ NMR spectrum (400 MHz, $\mathrm{CDCl}_{3}$, room temperature) of compound 2. 


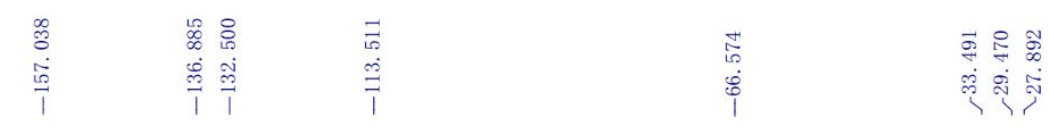

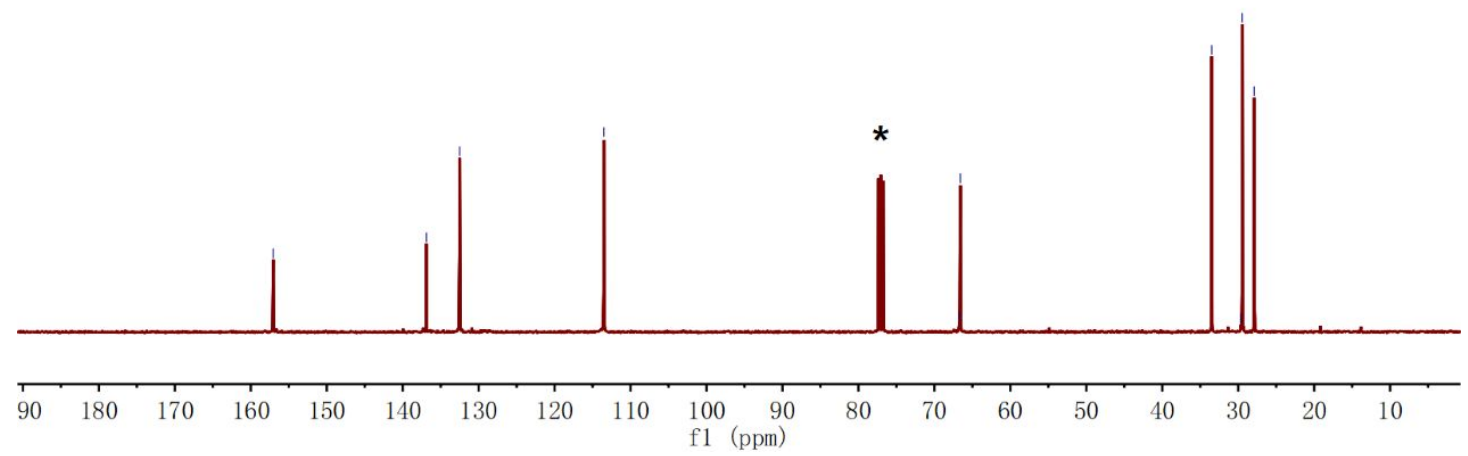

Fig. $\mathbf{S 1 3}{ }^{13} \mathrm{C}$ NMR spectrum (100 MHz, $\mathrm{CDCl}_{3}$, room temperature) of compound 2.

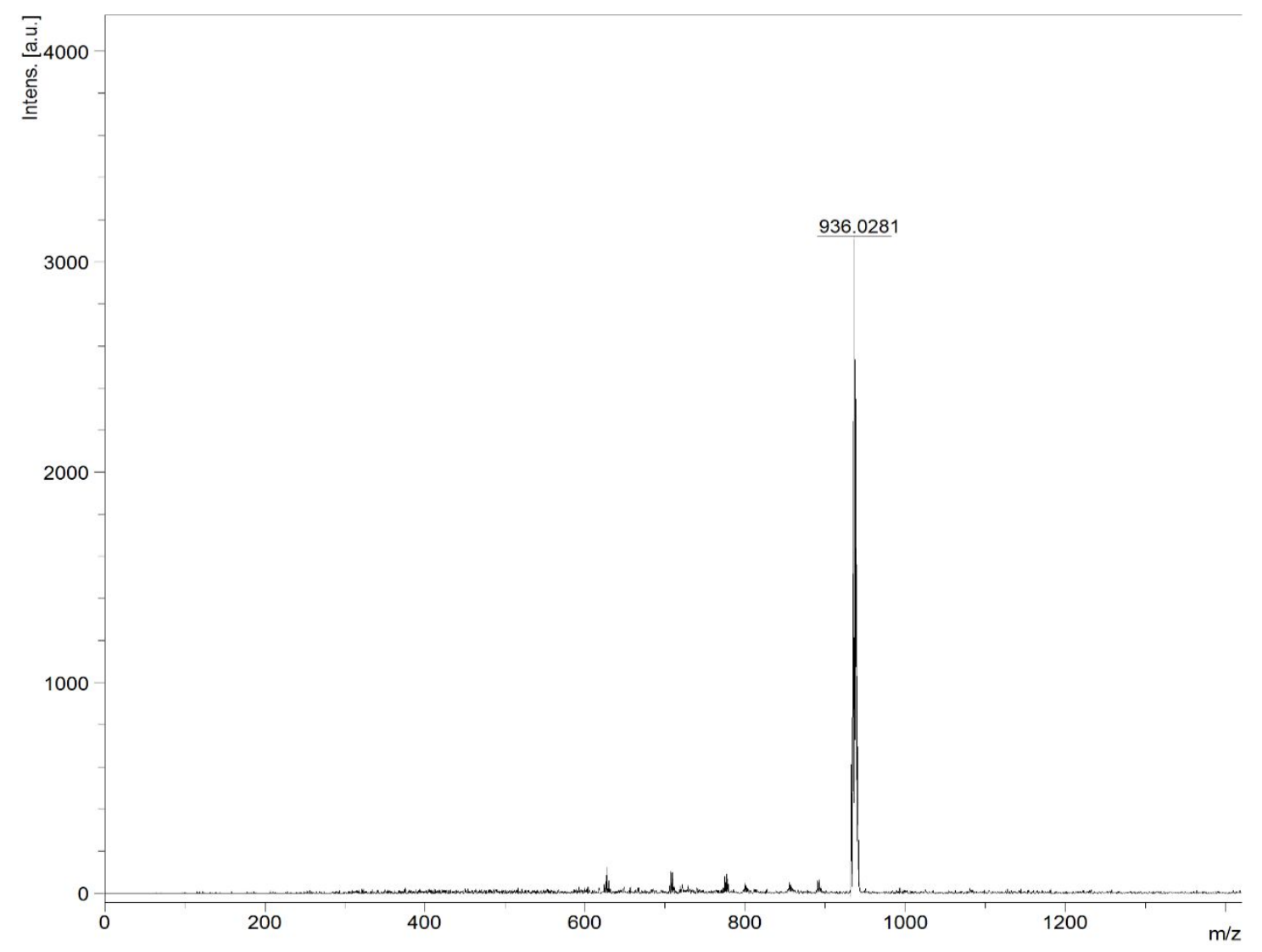

Fig. S14 High-resolution MALDI-TOF-MS of compound 2. 


\section{Synthesis of Compound N4}

A solution of $2(2.00 \mathrm{~g}, 2.1 \mathrm{mmol}), 3(6.20 \mathrm{~g}, 8.4 \mathrm{mmol})$ and $\mathrm{NaH}(0.40 \mathrm{~g}, 16.8 \mathrm{mmol})$ in DMF $(55 \mathrm{~mL})$ was stirred for $12 \mathrm{~h}$ at $75^{\circ} \mathrm{C}$. After the reaction mixture was cooled to ambient temperature, the solvent was evaporated under reduced pressure and the residue was partitioned between dichloromethane $(50 \mathrm{~mL})$ and water $(50 \mathrm{~mL})$. The aqueous layer was further washed with dichloromethane $(2 \times 50 \mathrm{~mL})$. The organic phases were combined and dried over anhydrous $\mathrm{Na}_{2} \mathrm{SO}_{4}$. After the solvent was removed, the resulting residue was subjected to column chromatography (dichloromethane /ethylacetate $=100: 1)$, to give $\mathrm{N} 4(3.36 \mathrm{~g}, 45 \%)$ as a white solid. ${ }^{1} \mathrm{H}$ NMR (400 $\left.\mathrm{MHz}, \mathrm{CDCl}_{3}, 298 \mathrm{~K}\right): \mathrm{ppm}=6.95(\mathrm{~d}, J=8.8 \mathrm{~Hz}, 8 \mathrm{H}), 6.79-6.72(\mathrm{~m}, 40 \mathrm{H}), 6.63(\mathrm{~d}, J=8.8 \mathrm{~Hz}, 8 \mathrm{H})$, 3.97-3.92(m, $8 \mathrm{H}), 3.89-3.82(\mathrm{~m}, 8 \mathrm{H}), 3.80-3.72(\mathrm{~m}, 40 \mathrm{H}), 3.68-3.61(\mathrm{~m}, 108 \mathrm{H}), 1.95-1.91(\mathrm{~m}, 16 \mathrm{H})$, ${ }^{13} \mathrm{C} \mathrm{NMR}\left(100 \mathrm{MHz}, \mathrm{CDCl}_{3}\right): \delta(\mathrm{ppm})=157.4,150.9,150.9,150.1,137.1,132.7,128.5,115.0,114.9$, 114.2, 114.1, 113.7, 68.2, 67.5, 55.9, 55.8, 29.9, 26.7, 26.5. MALDI-TOF-MS $\left(\mathrm{C}_{218} \mathrm{H}_{236} \mathrm{O}_{44}\right): \mathrm{m} / \mathrm{z}$ calcd for $[\mathrm{M}+\mathrm{H}]^{+}=3560.6369$, found $=3560.6431$, error $=1.7 \mathrm{ppm}$.

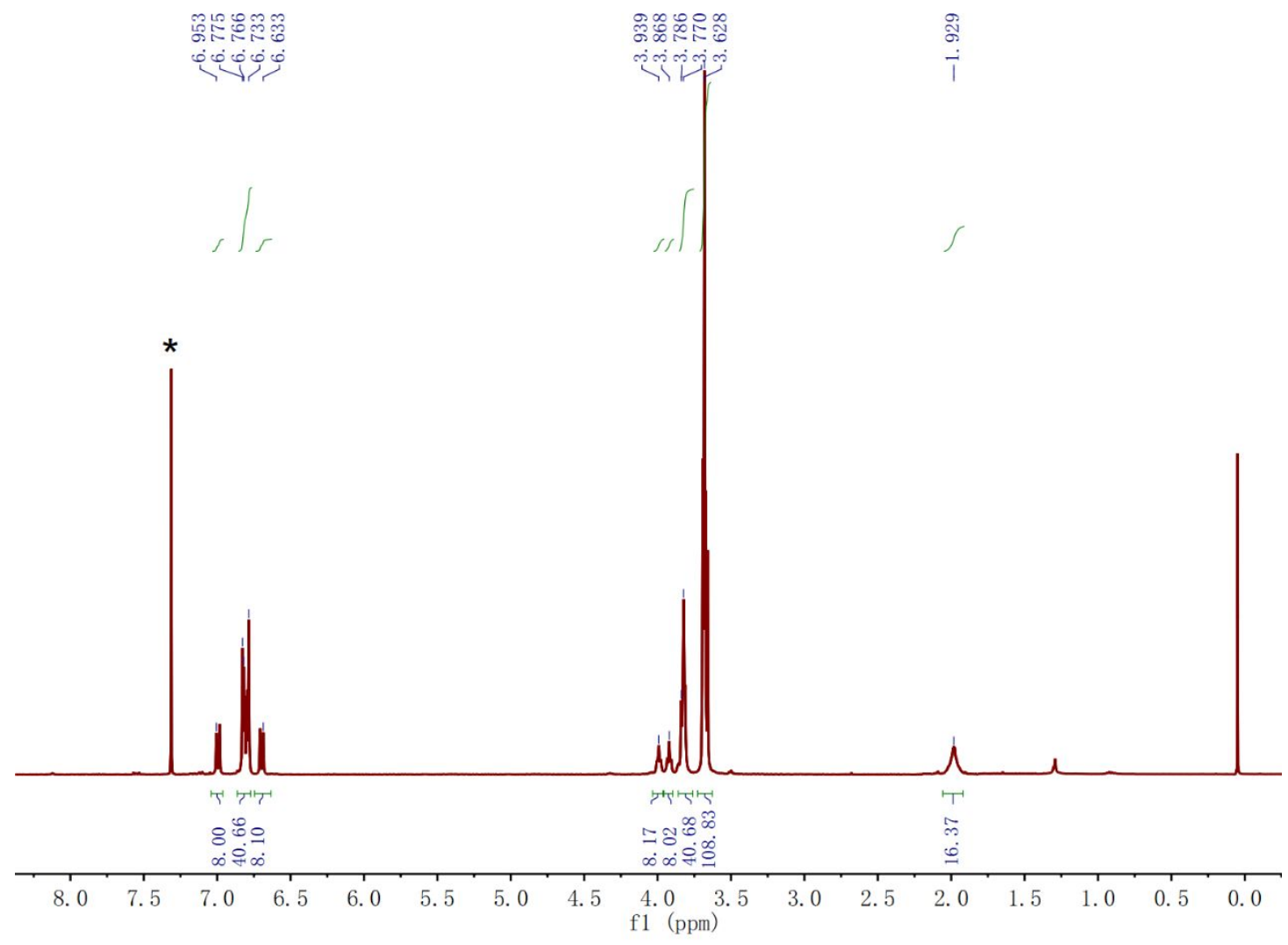

Fig. $\mathbf{S 1 5}{ }^{1} \mathrm{H}$ NMR spectrum (400 MHz, $\mathrm{CDCl}_{3}$, room temperature) of compound $\mathbf{N 4}$. 


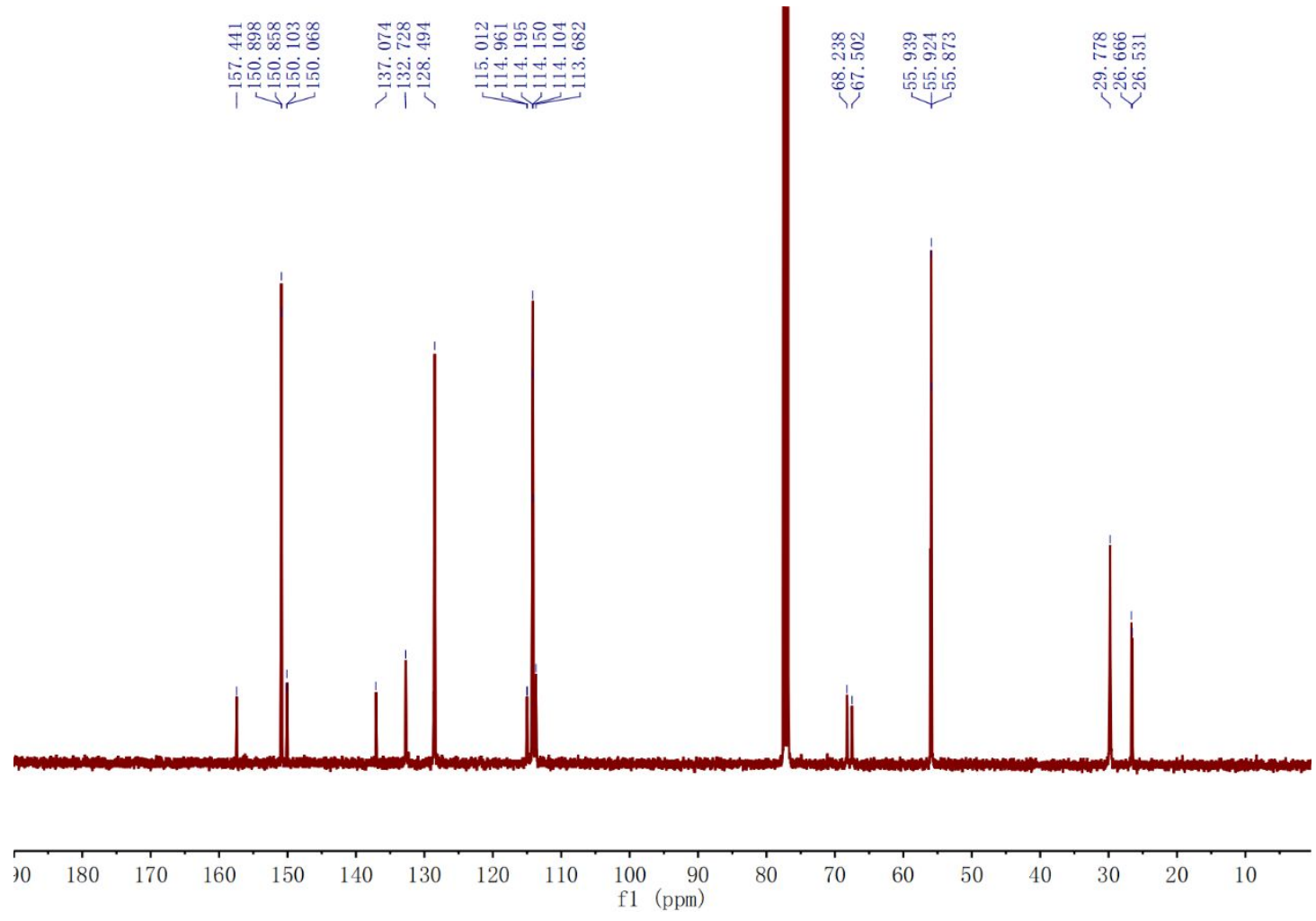

Fig. $\mathbf{S 1 6}{ }^{13} \mathrm{C}$ NMR spectrum (100 MHz, $\mathrm{CDCl}_{3}$, room temperature) of compound $\mathbf{N 4}$.

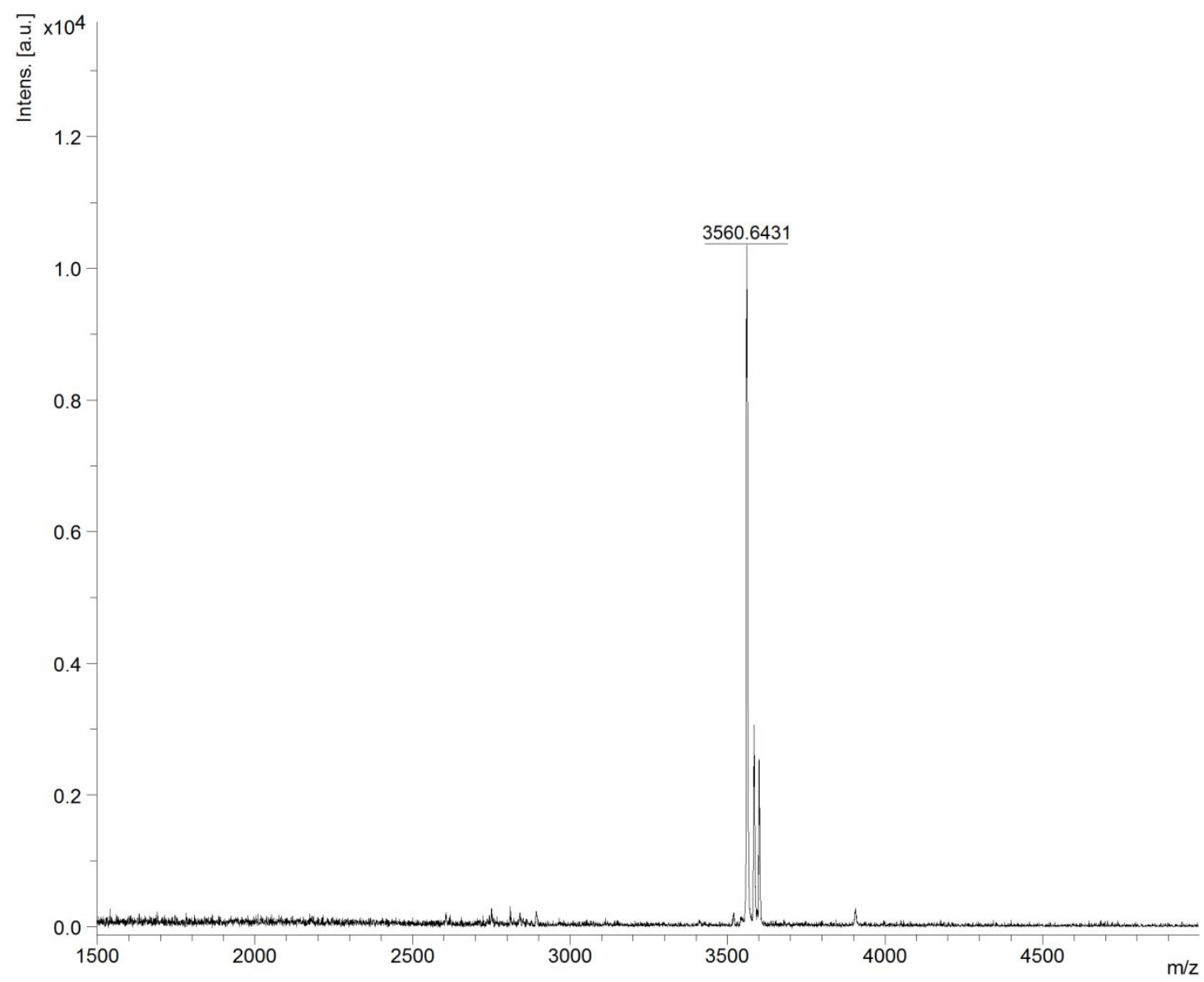




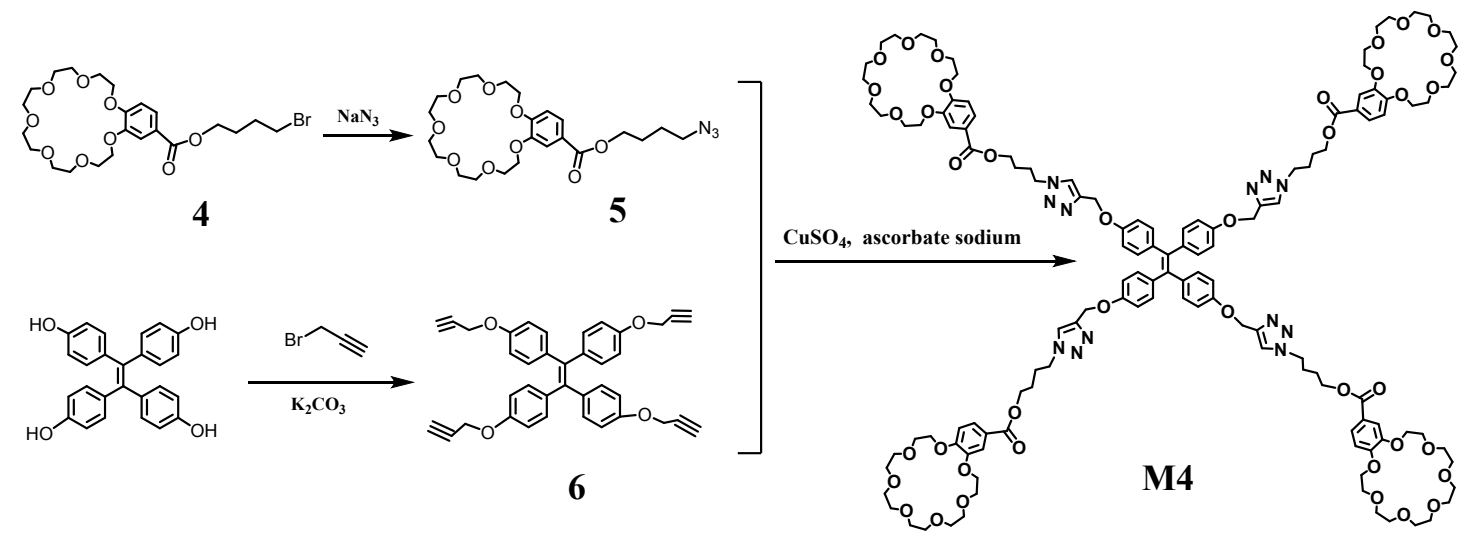

Scheme S3. Synthetic route of the compound M4.

\section{Synthesis of compound 5}

A solution of compound $4(2.00 \mathrm{~g}, 3.74 \mathrm{mmol})$, sodium azide $(0.60 \mathrm{~g}, 9.35 \mathrm{mmol})$ in acetone $(70 \mathrm{~mL})$ was stirred for $10 \mathrm{~h}$ at reflux. After the reaction mixture was cooled to ambient temperature, the solvent was evaporated under reduced pressure and the residue was partitioned between dichloromethane $(60 \mathrm{~mL})$ and water $(50 \mathrm{~mL})$. The aqueous layer was further washed with dichloromethane. The organic phases were combined and dried over anhydrous $\mathrm{Na}_{2} \mathrm{SO}_{4}$. After the solvent was removed, the resulting residue was subjected to column chromatography $\left(\mathrm{CH}_{2} \mathrm{Cl}_{2} / \mathrm{CH}_{3} \mathrm{OH}=60: 1\right)$, to give $5(1.76 \mathrm{~g}, 95 \%)$ as a white solid. ${ }^{1} \mathrm{H} \mathrm{NMR}\left(400 \mathrm{MHz}, \mathrm{CDCl}_{3}, 298\right.$ $\mathrm{K}): \mathrm{ppm}=7.63(\mathrm{~d}, J=8.4 \mathrm{~Hz}, 1 \mathrm{H}), 7.50(\mathrm{~s}, 1 \mathrm{H}), 6.85(\mathrm{~d}, J=8.4 \mathrm{~Hz}, 1 \mathrm{H}), 4.28(\mathrm{t}, J=6.2 \mathrm{~Hz}, 2 \mathrm{H})$, 4.19-4.13(m, 4H), 3.95-3.90(m, 4H), 3.79-3.71 (m, 4H), 3.70-3.66 (m, 4H), 3.65-3.60 (m, 8H), 3.33 $(\mathrm{t}, J=6.6 \mathrm{~Hz}, 2 \mathrm{H}), 1.84-1.78(\mathrm{~m}, 2 \mathrm{H}), 1.77-1.70(\mathrm{~m}, 2 \mathrm{H}),{ }^{13} \mathrm{C} \mathrm{NMR}\left(100 \mathrm{MHz}, \mathrm{CDCl}_{3}\right): \delta(\mathrm{ppm})=$ 166.2, 152.9, 148.3, 123.9, 122.9, 114.6, 112.3, 71.2, 71.1, 71.0, 70.9, 70.6, 69.6, 69.5, 69.3, 69.1, 64.0, 51.0, 26.1, 25.6. HR-ESI-MS $\left(\mathrm{C}_{23} \mathrm{H}_{35} \mathrm{~N}_{3} \mathrm{O}_{9}\right): \mathrm{m} / z$ calcd for $[\mathrm{M}+\mathrm{H}]^{+}=498.2446$, found $=498.2451$, error $1.0 \mathrm{ppm}$. 


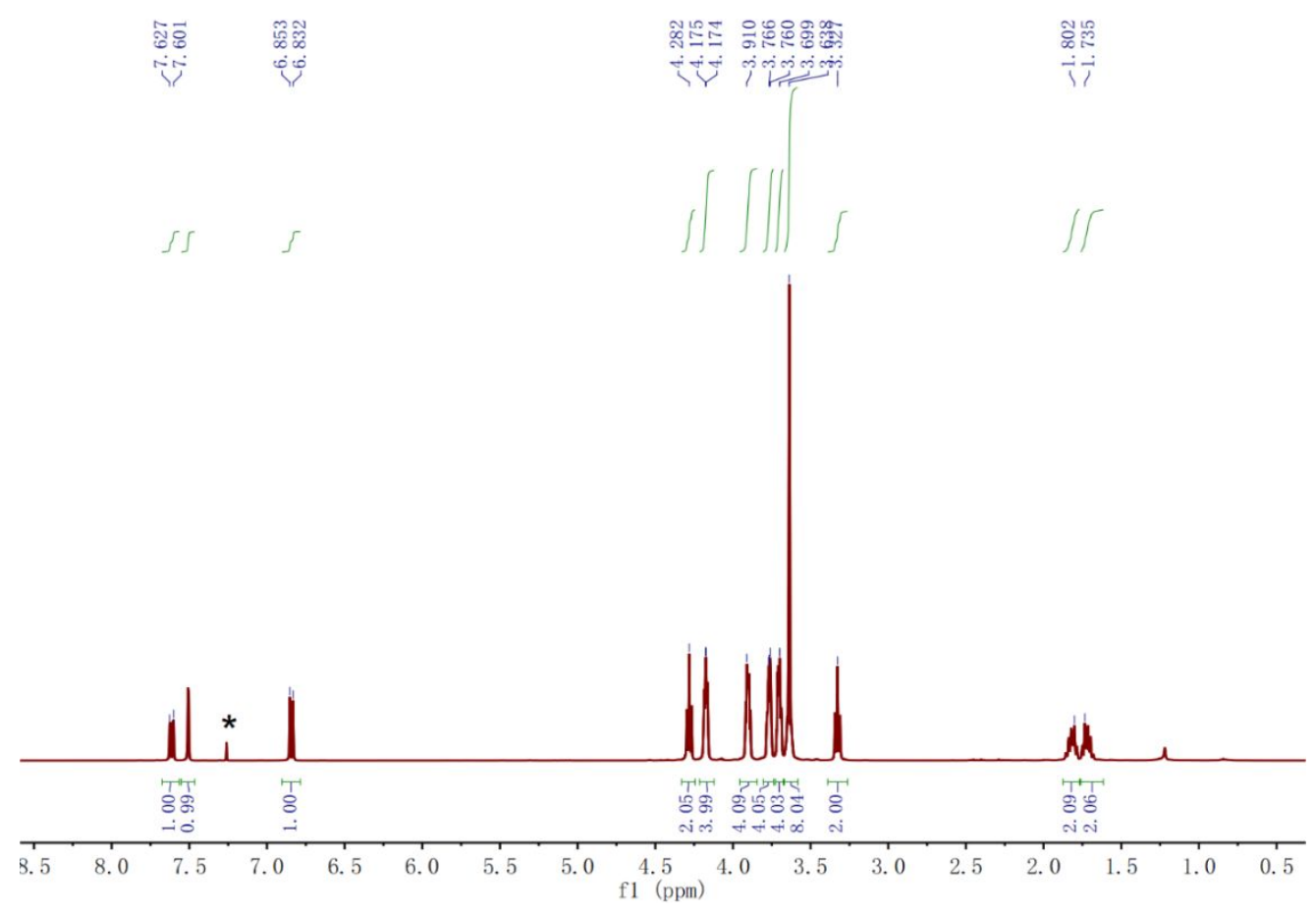

Fig. $\mathbf{S 1 8}{ }^{1} \mathrm{H}$ NMR spectrum (400 MHz, $\mathrm{CDCl}_{3}$, room temperature) of compound 5.

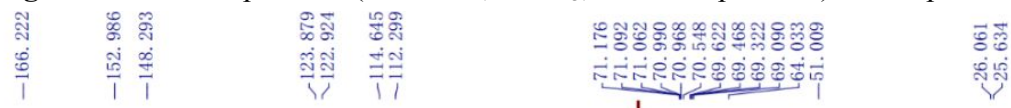
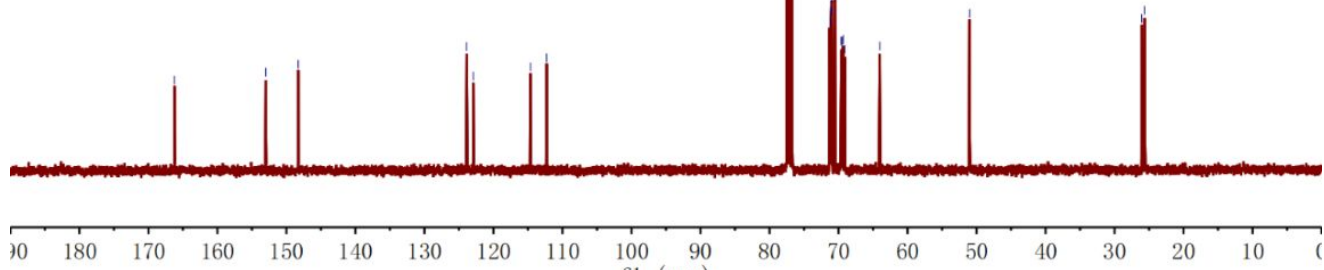

Fig. $\mathbf{S 1 9}{ }^{13} \mathrm{C}$ NMR spectrum (100 MHz, $\mathrm{CDCl}_{3}$, room temperature) of compound $\mathbf{5}$. 


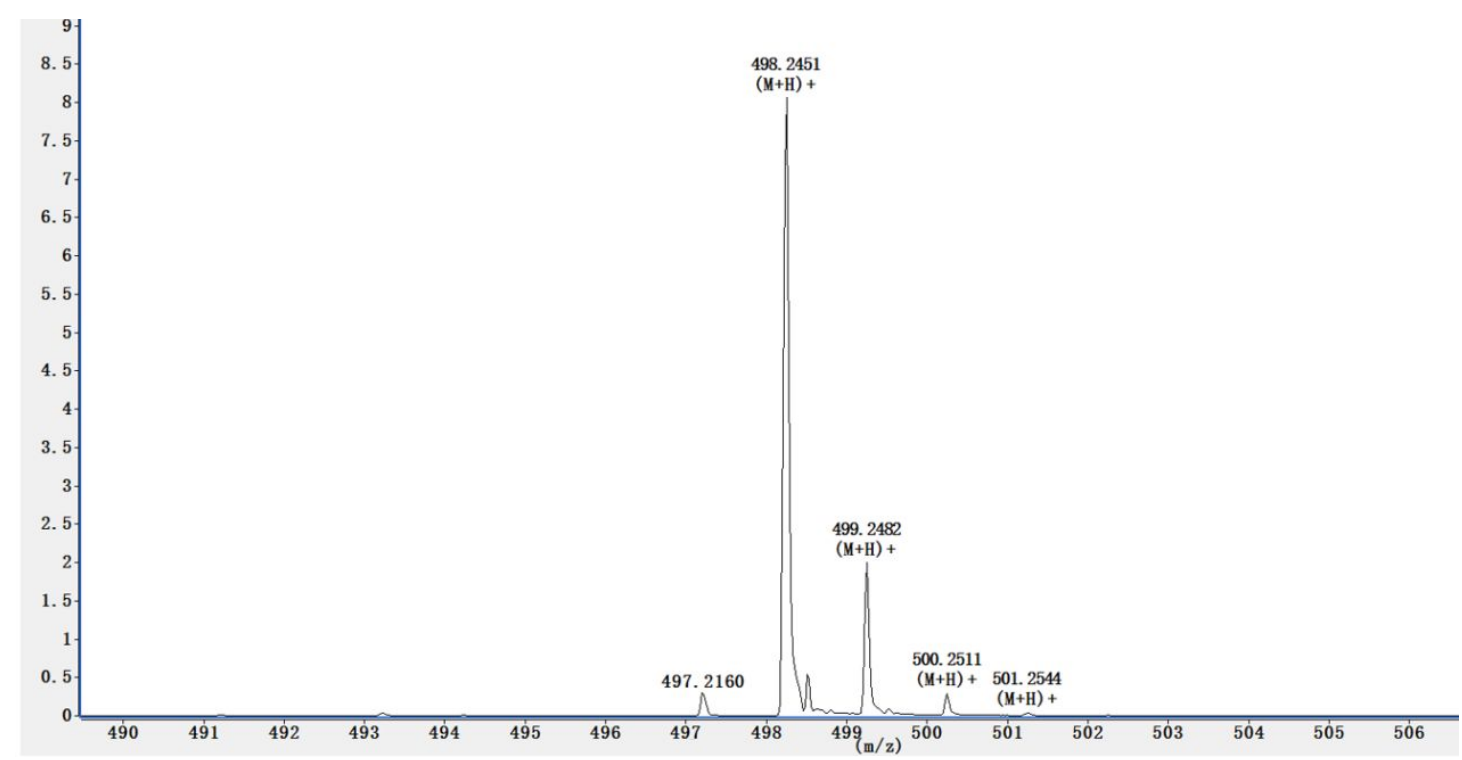

Fig. S20 High-resolution electrospray ionization mass spectrum of compound $\mathbf{5}$.

\section{Synthesis of monomer M4}

A mixture of $5(4.00 \mathrm{~g}, 8.0 \mathrm{mmol})$ and $6(1.00 \mathrm{~g}, 1.8 \mathrm{mmol})$ in a solution of THF and water $(10: 1,100$ $\mathrm{mL})$ in the presence of $\mathrm{CuSO}_{4} \cdot 5 \mathrm{H}_{2} \mathrm{O}(0.20 \mathrm{~g}, 0.8 \mathrm{mmol})$ with sodium ascorbate $(0.47 \mathrm{~g}, 2.4 \mathrm{mmol})$ was stirred at $65^{\circ} \mathrm{C}$ for $12 \mathrm{~h}$. After the reaction mixture was cooled to ambient temperature, the solvent was evaporated under reduced pressure and the resulting residue was subjected to column chromatography (dichloromethane / methanol $=40: 1)$, to afford M4 $(2.77 \mathrm{~g}, 60 \%)$ as a white solid. ${ }^{1} \mathrm{H} \mathrm{NMR}\left(400 \mathrm{MHz}, \mathrm{CDCl}_{3}, 298 \mathrm{~K}\right): \mathrm{ppm}=7.63(\mathrm{~d}, J=6.8 \mathrm{~Hz}, 8 \mathrm{H}), 7.53(\mathrm{~s}, 4 \mathrm{H}), 6.91(\mathrm{~d}, J=8.4 \mathrm{~Hz}$, $8 \mathrm{H}), 6.88(\mathrm{~d}, J=8.4 \mathrm{~Hz}, 8 \mathrm{H}), 6.73(\mathrm{~d}, J=8.4 \mathrm{~Hz}, 8 \mathrm{H}), 5.13(\mathrm{~s}, 8 \mathrm{H}), 4.44(\mathrm{t}, J=6.6 \mathrm{~Hz}, 8 \mathrm{H}), 4.32(\mathrm{t}$, $J=6.2 \mathrm{~Hz}, 8 \mathrm{H}), 4.25-4.17(\mathrm{~m}, 16 \mathrm{H}), 3.99-3.90(\mathrm{~m}, 16 \mathrm{H}), 3.83-3.76(\mathrm{~m}, 16 \mathrm{H}), 3.74-3.68(\mathrm{~m}, 16 \mathrm{H})$, $3.67-3.60(\mathrm{~m}, 32 \mathrm{H}), 2.10-2.06(\mathrm{~m}, 8 \mathrm{H}), 1.85-1.81(\mathrm{~m}, 8 \mathrm{H}) .{ }^{13} \mathrm{C} \mathrm{NMR}\left(100 \mathrm{MHz}, \mathrm{CDCl}_{3}\right): \delta(\mathrm{ppm})=$ $166.3,156.8,153.2,148.5,144.4,138.7,137.3,132.7,124.1,122.9,122.7,114.8,114.0,112.4,71.4$, $71.3,71.2,71.2,71.1,71.1,70.7,69.8,69.6,69.5,69.2,63.8,62.1,50.0,29.8,27.2,25.9$. HR-ESIMS $\left(\mathrm{C}_{130} \mathrm{H}_{168} \mathrm{~N}_{12} \mathrm{O}_{40}\right): \mathrm{m} / \mathrm{z}$ calcd for $[\mathrm{M}+\mathrm{Na}]^{+}=2561.1407$, found $=2561.1452$, error $=1.8 \mathrm{ppm}$. 


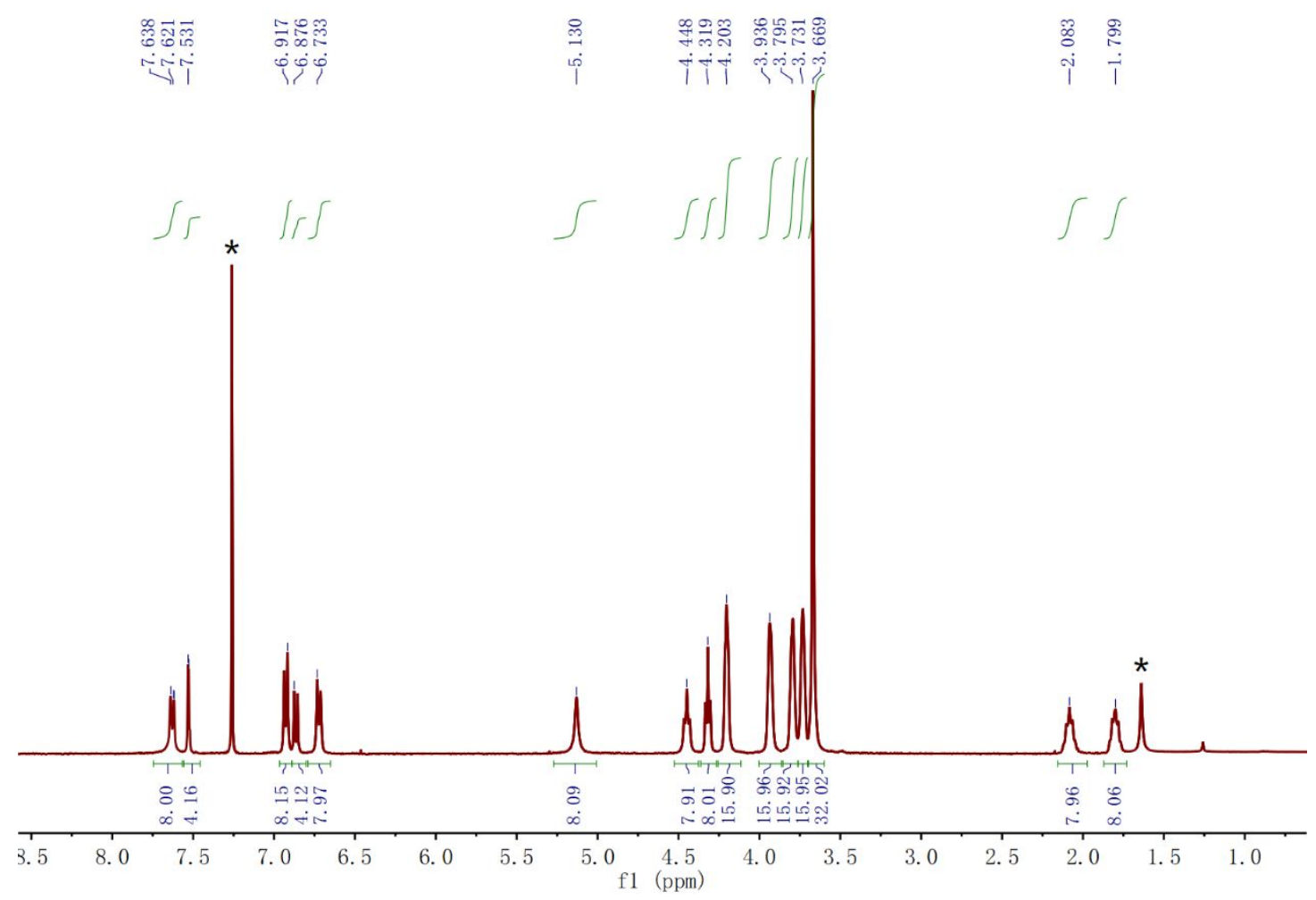

Fig. S21 ${ }^{1} \mathrm{H}$ NMR spectrum (400 MHz, $\mathrm{CDCl}_{3}$, room temperature) of compound M4.

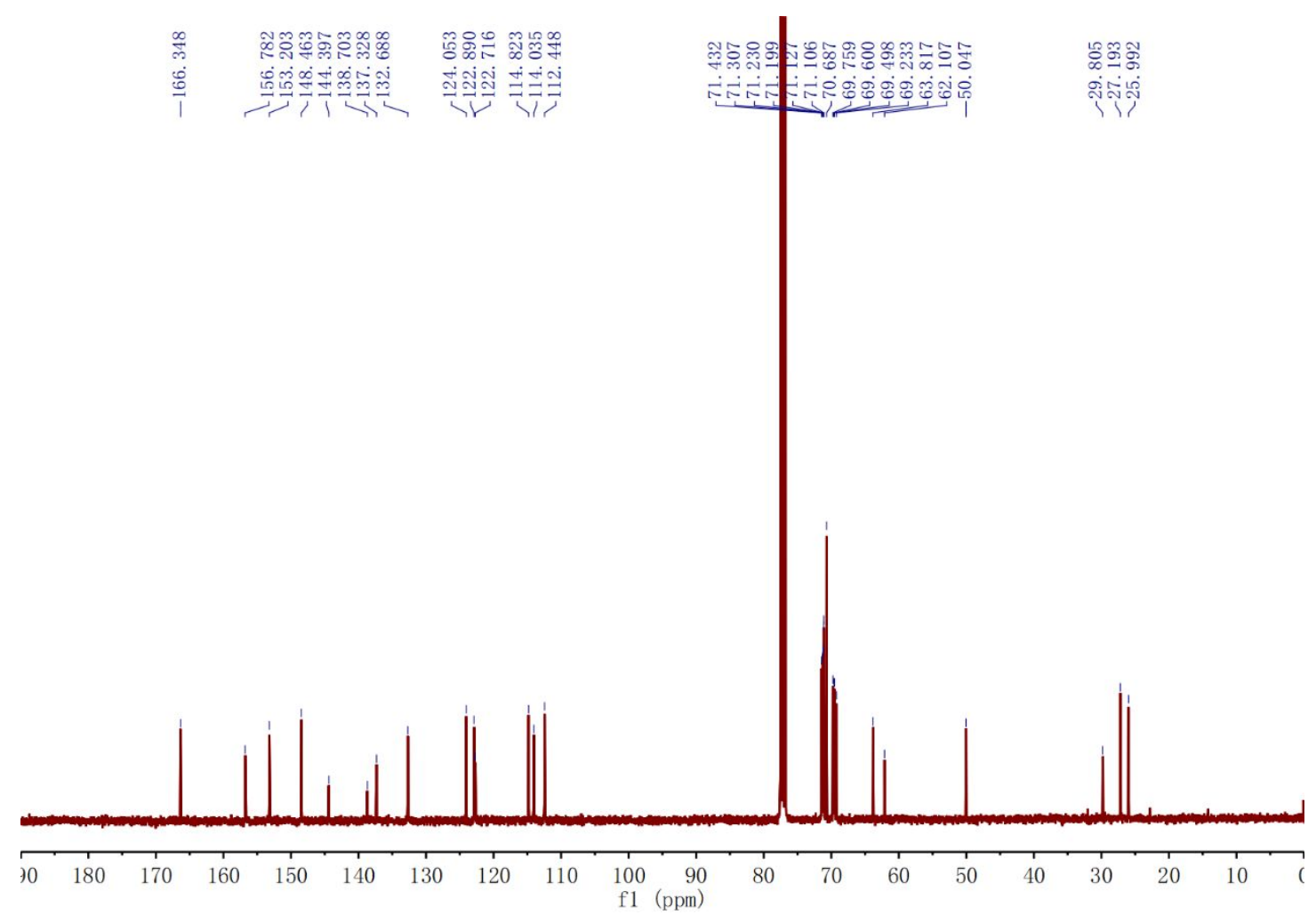

Fig. $\mathbf{S 2 2}{ }^{13} \mathrm{C}$ NMR spectrum ( $100 \mathrm{MHz}, \mathrm{CDCl}_{3}$, room temperature) of compound M4. 


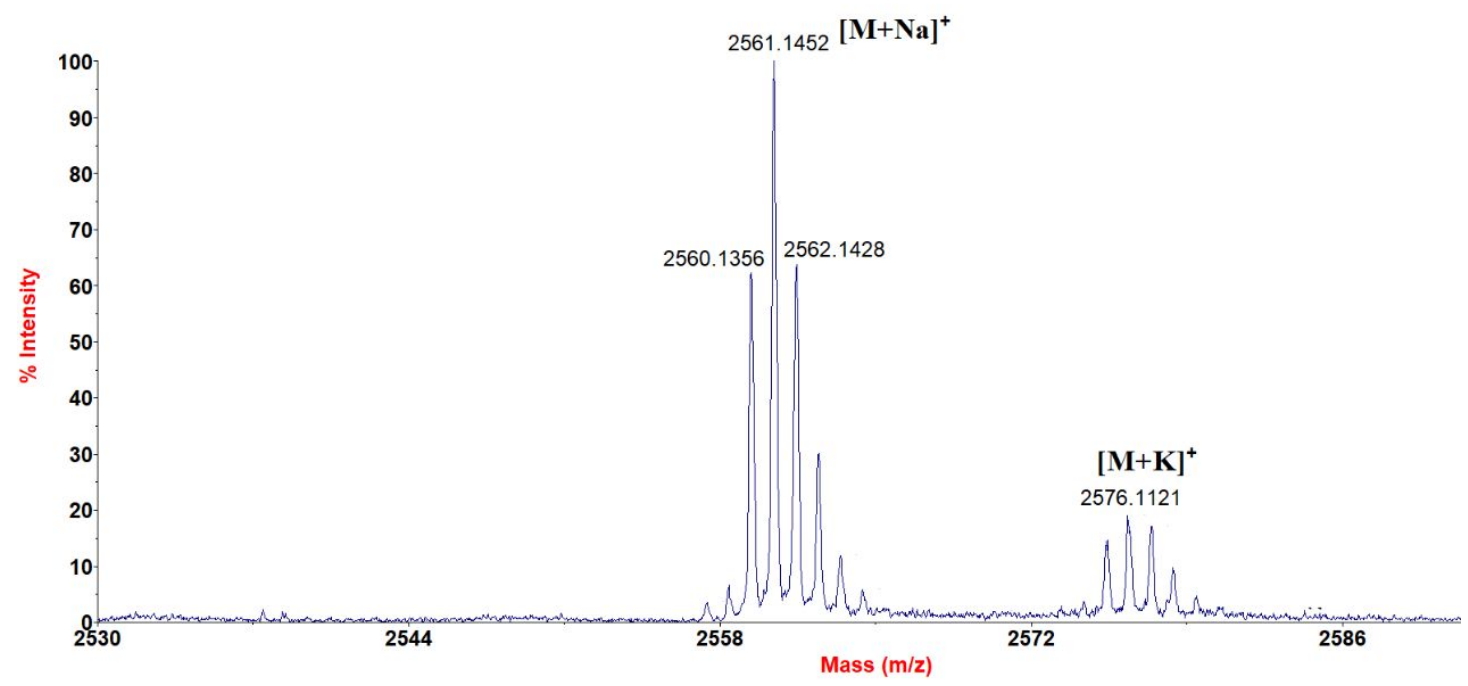

Fig. S23 High-resolution MALDI-TOF-MS of compound M4.
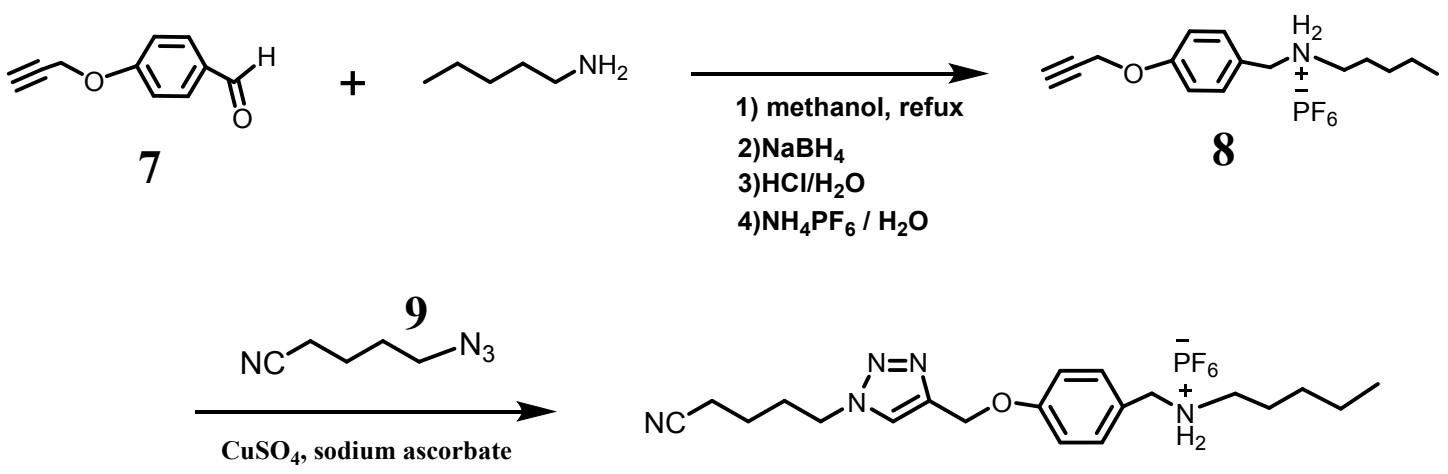

AE

Scheme S4. Synthetic route of monomer AE.

\section{Synthesis of compound 8}

Compound $7(2.00 \mathrm{~g}, 12.4 \mathrm{mmol})$ and pentylamine $(1.2 \mathrm{~g}, 13.8 \mathrm{mmol})$ were dissolved in methanol $(60 \mathrm{~mL})$ and heated at $65{ }^{\circ} \mathrm{C}$ under $\mathrm{N}_{2}$ atmosphere overnight. After the reaction mixture was cooled to ambient temperature, $\mathrm{NaBH}_{4}(1.41 \mathrm{~g}, 37.2 \mathrm{mmol})$ was added to the solution in small portion and the mixture was stirred at room temperature for another $12 \mathrm{~h}$. Water $(30 \mathrm{~mL})$ was added to quench the remaining $\mathrm{NaBH}_{4}$, and $2 \mathrm{M} \mathrm{HCl}$ was added to acidify the amine. The solvent was removed under reduced pressure to give a white solid which was dissolved in deionized water/methanol $(200 \mathrm{~mL}$, 5:1, v/v). A saturated aqueous solution of $\mathrm{NH}_{4} \mathrm{PF}_{6}$ was added to afford a white precipitate which was filtered off and washed with deionized water to afford 8 as a white solid $(1.29 \mathrm{~g}, 45 \%) .{ }^{1} \mathrm{H}$ NMR $\left(400 \mathrm{MHz}, \mathrm{CD}_{3} \mathrm{COCD}_{3}, 298 \mathrm{~K}\right): \mathrm{ppm}=7.58(\mathrm{~d}, J=8.4 \mathrm{~Hz}, 2 \mathrm{H}), 7.07(\mathrm{~d}, J=8.8 \mathrm{~Hz}, 2 \mathrm{H}), 4.43(\mathrm{~s}$, $2 \mathrm{H}), 4.48(\mathrm{~s}, 2 \mathrm{H}), 3.33-3.28(\mathrm{~m}, 2 \mathrm{H}), 3.11(\mathrm{~s}, 1 \mathrm{H}), 1.90-1.85(\mathrm{~m}, 2 \mathrm{H}), 1.40-1.33(\mathrm{~m}, 4 \mathrm{H}), 0.89(\mathrm{t}, J=$ 
$7.0 \mathrm{~Hz}, 3 \mathrm{H}) .{ }^{13} \mathrm{C} \mathrm{NMR}\left(100 \mathrm{MHz}, \mathrm{CD}_{3} \mathrm{CN}\right): \delta(\mathrm{ppm})=159.2,132.6,124.3,116.0,79.3,76.9,56.4$, 51.7, 48.5, 28.9, 26.0, 22.5, 13.9. HR-ESI-MS $\left(\mathrm{C}_{15} \mathrm{H}_{22} \mathrm{~F}_{6} \mathrm{NOP}\right): \mathrm{m} / z$ calcd for $\left[\mathrm{M}-\mathrm{PF}_{6}{ }^{-}\right]^{+}=232.1696$, found $=232.1691$, error $=2.1 \mathrm{ppm}$.
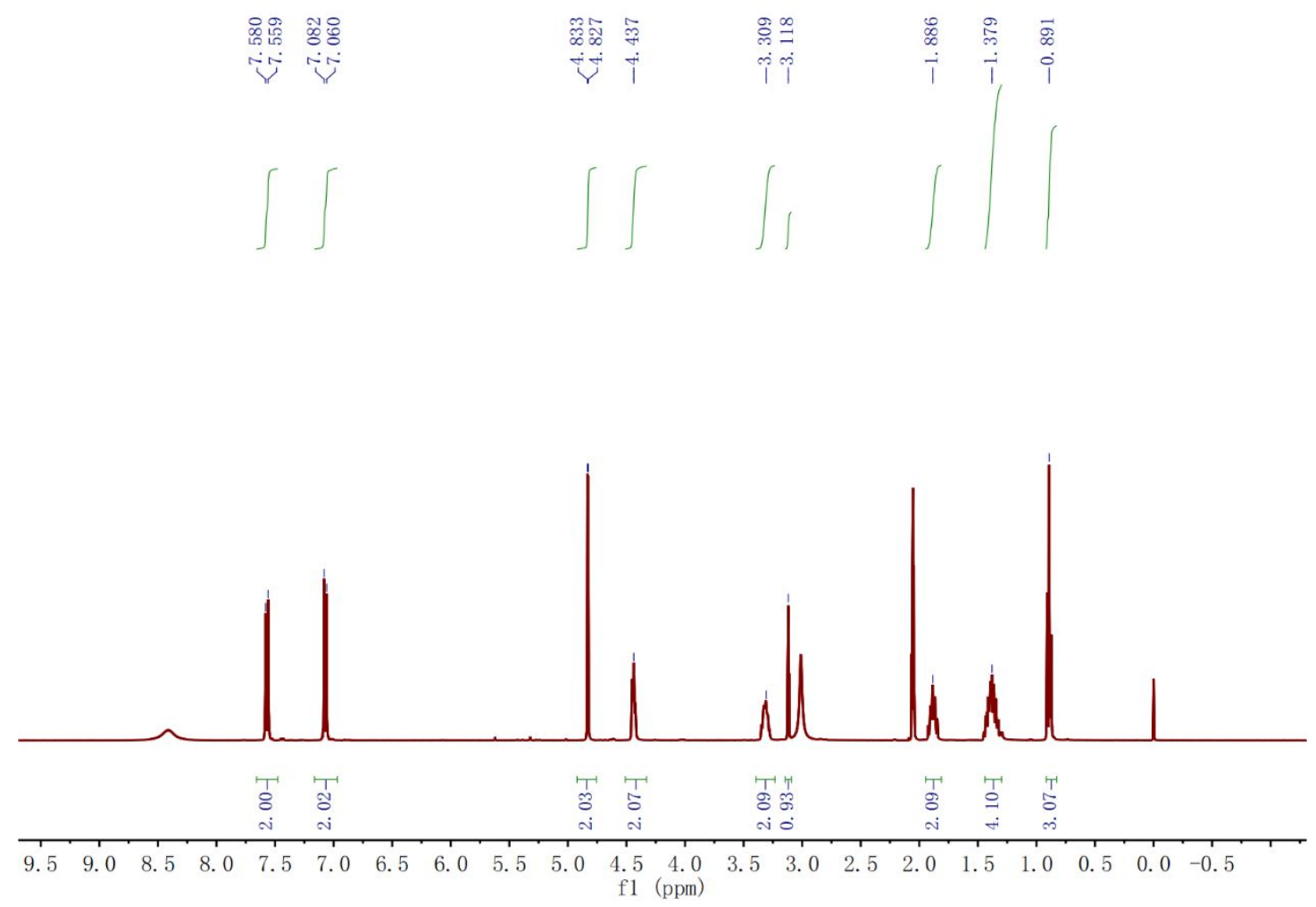

Fig. S24 ${ }^{1} \mathrm{H}$ NMR spectrum (400 MHz, $\left.\mathrm{CDCl}_{3}, 298 \mathrm{~K}\right)$ of compound $\mathbf{8}$.

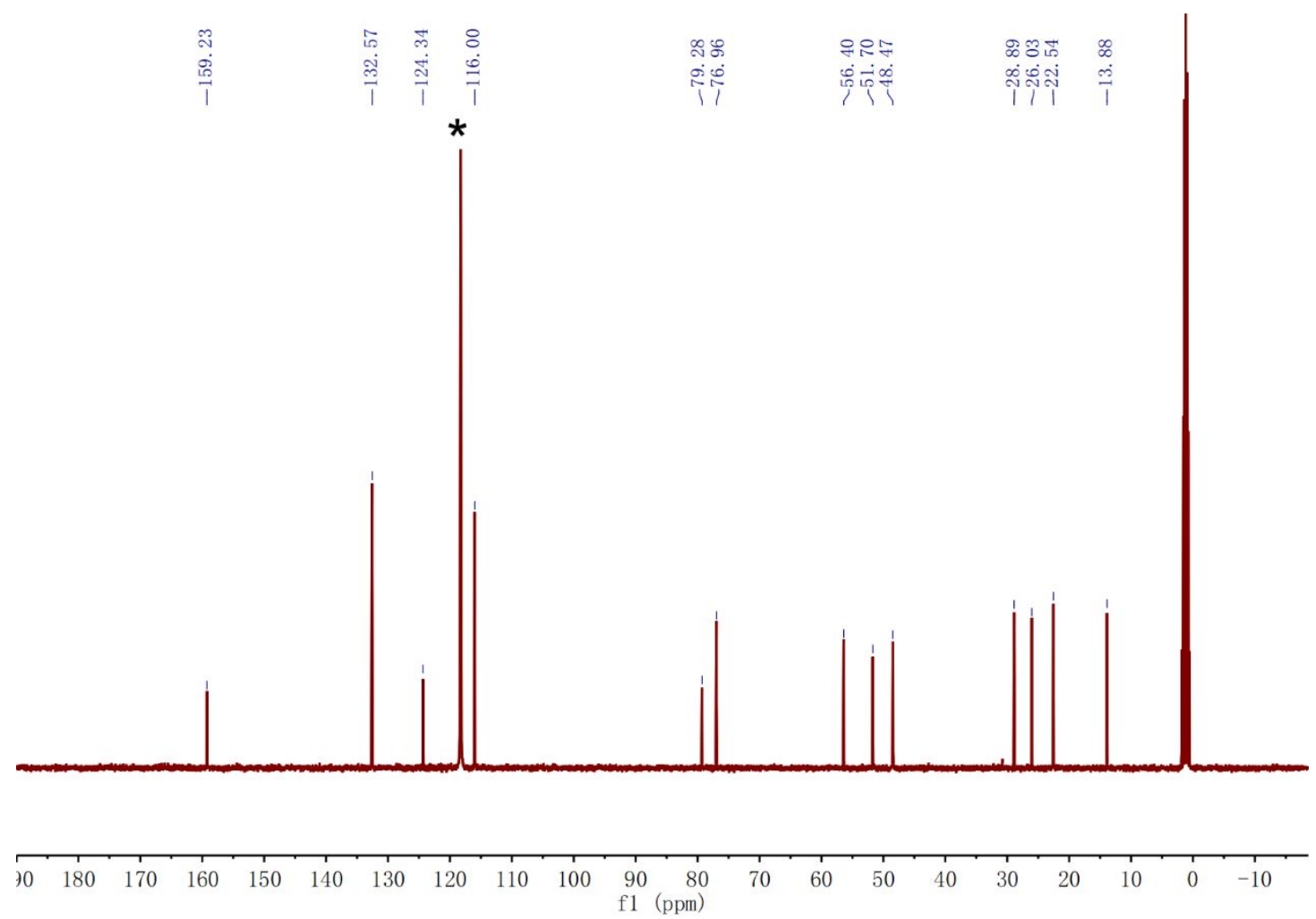


Fig. $\mathbf{S 2 5}{ }^{13} \mathrm{C}$ NMR spectrum $\left(100 \mathrm{MHz}, \mathrm{CDCl}_{3}, 298 \mathrm{~K}\right)$ of compound $\mathbf{8}$.

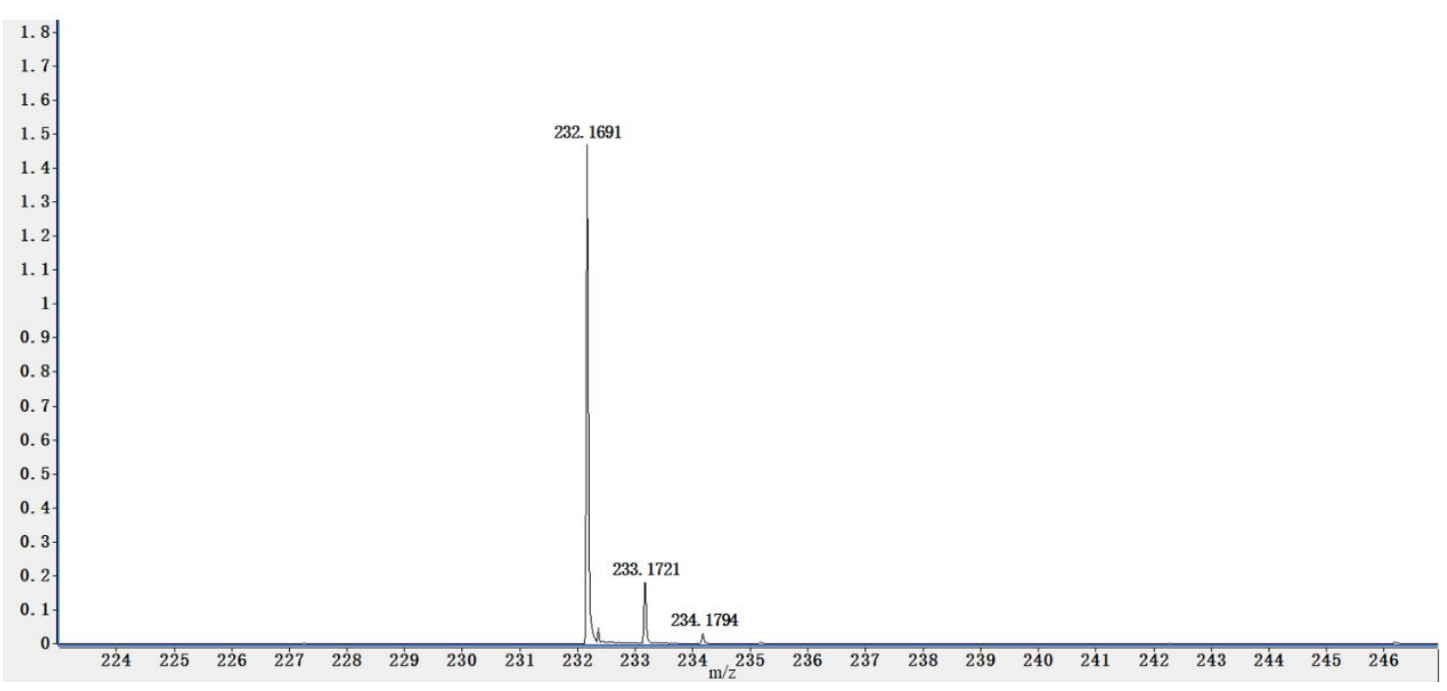

Fig. S26 High-resolution electrospray ionization mass spectrum of compound $\mathbf{8}$.

\section{Synthesis of monomer AE}

A mixture of $8(1.88 \mathrm{~g}, 5.0 \mathrm{mmol})$ and $9(0.62 \mathrm{~g}, 5.0 \mathrm{mmol})$ in a solution of tetrahydrofuran and water $(3: 1,60 \mathrm{~mL})$ in the presence of $\mathrm{CuSO}_{4} \cdot 5 \mathrm{H}_{2} \mathrm{O}(61.2 \mathrm{mg}, 0.25 \mathrm{mmol})$ with sodium ascorbate $\left(138.7 \mathrm{mg}, 0.70 \mathrm{mmol}\right.$ ) was stirred at $65^{\circ} \mathrm{C}$ for $14 \mathrm{~h}$. The reaction mixture was poured into saturated brine $(100 \mathrm{~mL})$ and the resulting solution was extracted with dichloromethane $(50 \mathrm{~mL} \times 3)$. The combined organic phase was concentrated and purified by flash column chromatography $\left(\mathrm{CH}_{2} \mathrm{Cl}_{2} / \mathrm{CH}_{3} \mathrm{OH}, 30: 1 v / v\right)$ to afford compound $\mathrm{AE}$ as a white solid (1.37 g, 55\%).

${ }^{1} \mathrm{H} \mathrm{NMR}\left(400 \mathrm{MHz}, \mathrm{CD}_{3} \mathrm{CN}, 298 \mathrm{~K}\right): \mathrm{ppm}=8.45-8.37(\mathrm{br}, 2 \mathrm{H}), 7.89(\mathrm{~s}, 1 \mathrm{H}), 7.39(\mathrm{~d}, J=8.8 \mathrm{~Hz}, 2 \mathrm{H})$, $7.10(\mathrm{~d}, J=8.8 \mathrm{~Hz}, 2 \mathrm{H}), 5.19(\mathrm{~s}, 2 \mathrm{H}), 4.41(\mathrm{t}, J=6.4 \mathrm{~Hz}, 2 \mathrm{H}), 4.10(\mathrm{~s}, 2 \mathrm{H}), 3.01(\mathrm{t},(\mathrm{d}, J=7.8 \mathrm{~Hz}$, $2 \mathrm{H}), 2.42(\mathrm{t}, J=7.0 \mathrm{~Hz}, 2 \mathrm{H}), 2.02-1.95(\mathrm{~m}, 2 \mathrm{H}), 1.64-1.60(\mathrm{~m}, 4 \mathrm{H}), 1.36-1.30(\mathrm{~m}, 4 \mathrm{H}), 0.90(\mathrm{t}, J=7.0$ $\mathrm{Hz}, 3 \mathrm{H}) .{ }^{13} \mathrm{C} \mathrm{NMR}\left(100 \mathrm{MHz}, \mathrm{CD}_{3} \mathrm{CN}\right): \delta(\mathrm{ppm})=144.1,132.7,125.1,124.0,120.9,116.2,62.4$, 52.0, 50.2, 48.7, 29.9, 29.1, 26.2, 23.2, 22.7, 17.0, 14.0. HR-ESI-MS $\left(\mathrm{C}_{20} \mathrm{H}_{30} \mathrm{~F}_{6} \mathrm{~N}_{5} \mathrm{OP}\right): \mathrm{m} / \mathrm{z}$ calcd for $\left[{\mathrm{M}-\mathrm{PF}_{6}}^{-}\right]^{+}=356.2445$, found $=356.2446$, error=0.3ppm. Elemental analysis: C, 47.90; H, 6.03; N, 13.97; F, 22.73, found= C, 47.94; H, 6.02; N, 13.99; F, 22.69. 


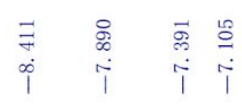
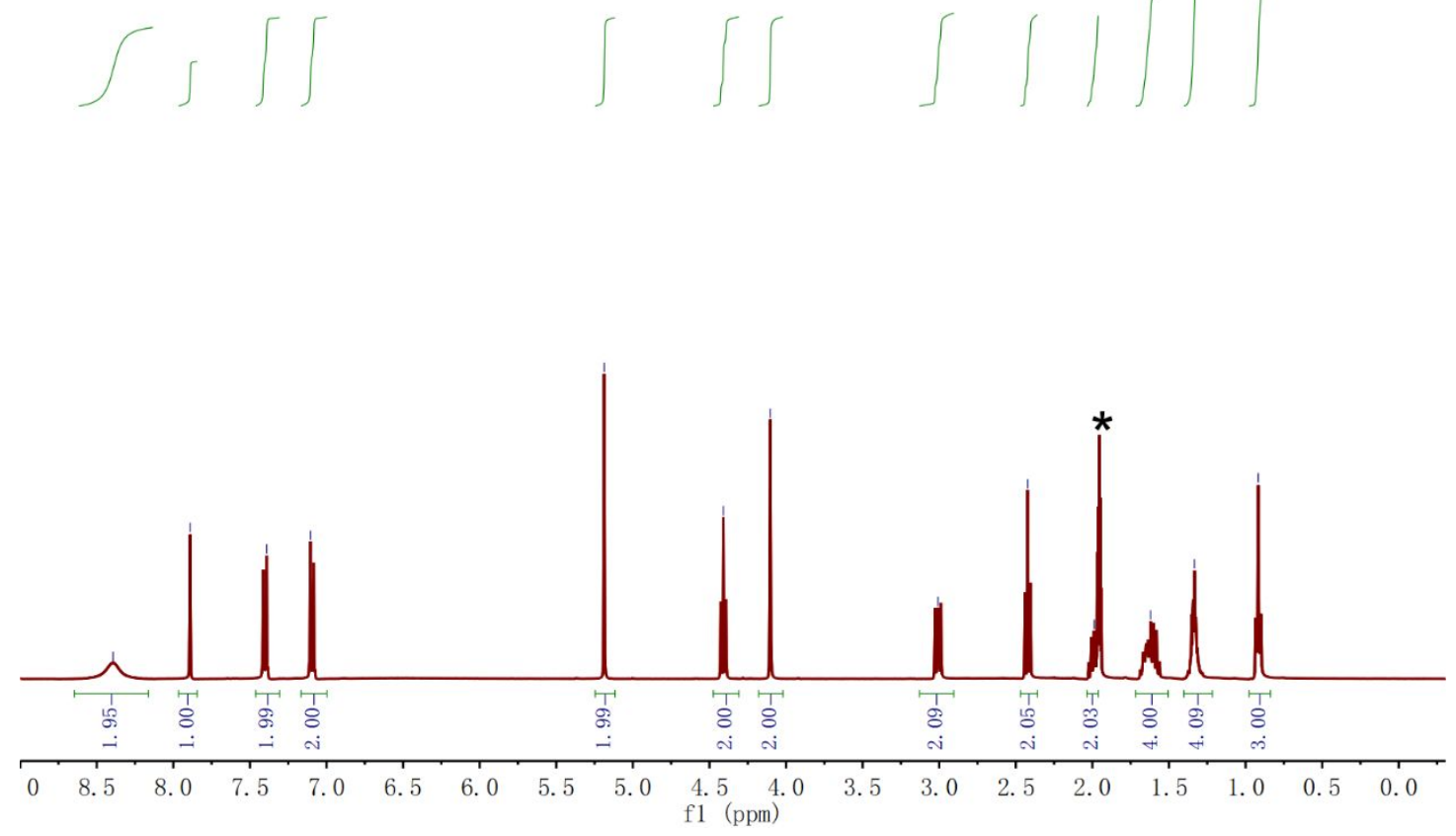

Fig. S27 ${ }^{1} \mathrm{H}$ NMR spectrum (400 MHz, $\left.\mathrm{CD}_{3} \mathrm{CN}, 298 \mathrm{~K}\right)$ of compound AE.
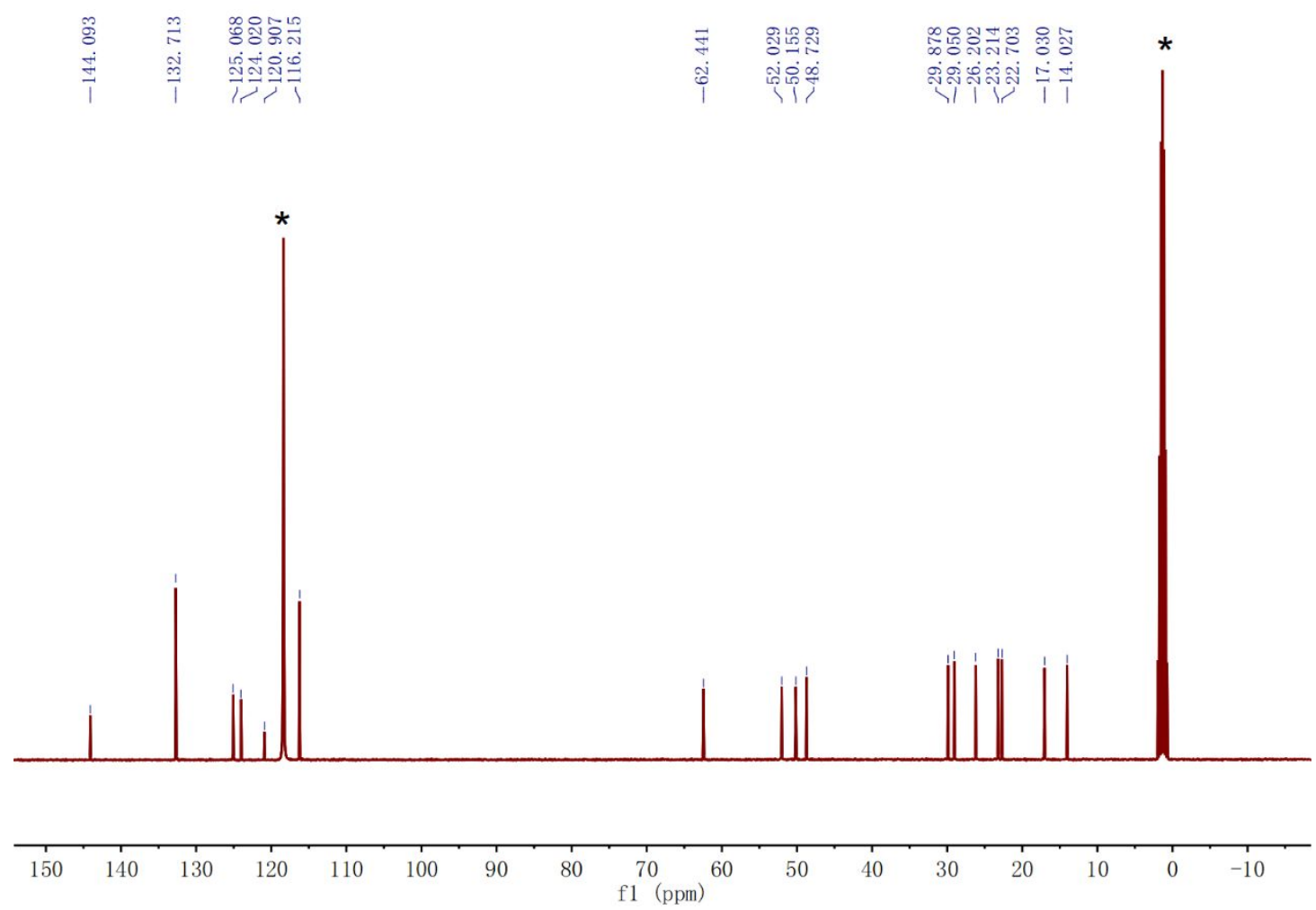

Fig. S28 ${ }^{13} \mathrm{C}$ NMR spectrum (100 MHz, $\left.\mathrm{CD}_{3} \mathrm{CN}, 298 \mathrm{~K}\right)$ of compound AE. 


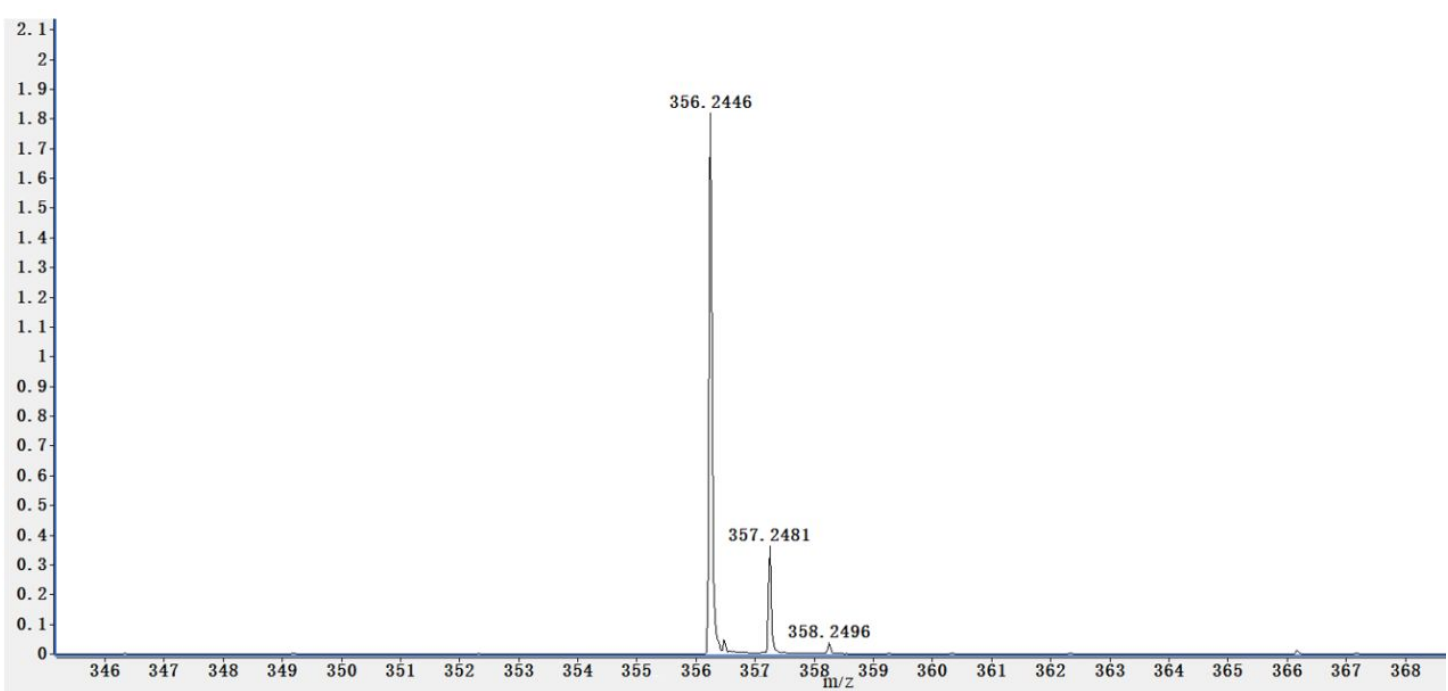

Fig. S29 High-resolution electrospray ionization mass spectrum of compound AE.

\section{Reference:}

S1. Zhang, C. J.; Li, S. J.; Zhang, J. Q.; Zhu, K. L.; Li, N.; Huang, F. H. Benzo-21-Crown-7/Secondary Dialkylammonium Salt [2]Pseudorotaxane- and [2]Rotaxane-Type Threaded Structures. Org. Lett., 2007, 9 , 5553-5556.

S2. Li, H.; Fan, X. D.; Qi, M.; Yang, Z.; Zhang, H. T.; Tian, W. Supramolecular Alternating Polymer from Crown Ether and Pillar[5]arene-Based Double Molecular Recognition for Preparation of Hierarchical Materials. Chem. - Eur. J., 2016, 22, 101-105. 